Schäfer, A.I. ; Semião, A. ; Akanyeti, I. (2011)

Micropollutant sorption to membrane polymers, Advances in Colloid and Interface Science, 'Membrane Separation and Colloid Science' invited special issue paper (accepted 09/2010). doi:10.1016/j.cis.2010.09.006

\section{Micropollutant Sorption to Membrane Polymers: A Review of Mechanisms for Estrogens}

Andrea I. Schäfer ${ }^{*}$, Ime Akanyeti, Andrea J.C. Semião

School of Engineering, The University of Edinburgh, Edinburgh EH9 3JL, United Kingdom;

Submitted to

Special Issue of "Advances in Colloid and Interface Science" on "Colloid Science and Membrane Separation"

18 March 2010

Revision submitted

26 September 2010

\section{Abstract}

Organic micropollutants such as estrogens occur in water in increasing quantities from predominantly anthropogenic sources. In water such micropollutants partition to surfaces such as membrane polymers but also any other natural or treatment related surfaces. Such interactions are often observed as sorption in treatment processes and this phenomenon is exploited in activated carbon filtration, for example. Sorption is important for polymeric materials and this is used for the concentration of such micropollutants for analytical purposes in solid phase extraction. In membrane filtration the mechanism of micropollutant sorption is a relative new discovery that was facilitated through new facilitated throgh in micropollutant retention by membranes although mechanisms of interaction are to date not understood. This review is focused on sorption of estrogens on polymeric surfaces, specifically membrane polymers. Such sorption has been observed to a large extent with values of up to 1.2 $\mathrm{ng} / \mathrm{cm}^{2}$ measured. Sorption is dependent on the type of polymer, micropollutant characteristics, solution chemistry, membrane operating conditions as well as membrane morphology. Likely contributors to sorption are the surface roughness as well as the microporosity of such polymers While retention - or and reflection coefficient as well as solute to effective pore size ratio - control the access of such micropollutants to the inner surface, pore size, porosity and thickness as well as morphology or shape of iner voids determines the avalable area for sorption. The interactio (n) mechanisns are govened, most molecular and supramolecular interactions such as hydrogen bonding, $\pi$-cation/anion interactions, $\pi-\pi$ stacking, ion-dipole and dipole-dipole interactions, the extent of which is naturally dependent on micropollutant and polymer characteristics. Systematic investigations are required to identify and quantify both relative contributions and strength of such interactions and develop suitable surface characterisation tools. This is a difficult endeavour given the complexity of systems, the possibility of several interactions taking place simultaneously and the generally weaker forces involved.
Keywords

Sorption, micropollutant, membrane polymer, hydrogen bonding, supramolecular interactions, nanofiltration.

\section{Introduction}

Micropollutants in water are a rapidly emerging global problem that seriously threatens environmental and human health. This can be attributed to the interference with hormonal functions such as behavioural development and fertility. Micropollutants are natural as well as anthropogenic persistent chemicals, such as pesticides, pharmaceuticals, personal care products, plasticizers, and many other groups such as antibiotics, hormones and endocrine disrupters. Many micropollutants accumulate in the environment due to their persistence and increasingly occur in water at measurable concentrations [1-3]. There has been much debate on the health effect of adverse effects on mammals from water sources is still being established, due to increasing regulations and for precautionary reasons the removal of those pollutants has become a priority.

Many contaminants originate from wastewater effluents where relatively high concentrations $(\mu \mathrm{g} / \mathrm{L})$ such as pharmaceuticals and antidepressants have been measured. This evidences an incomplete removal by conventional treatment processes [7-16]. While synthetic steroid hormones (such as contraceptive pill, menopause or chemotherapy drugs) generally only occur at trace level concentrations in wastewater effluents, in US streams concentrations of steroid to hormones of hormones were measured [17]. This was attibuted to effluent discharge. Wells in the vicinity of a WWTP have higher concentrations of pharnacenticals (up to $300 \mathrm{ng} / \mathrm{L}$ ) compared to othe upstream wells $(<50 \mathrm{ng} / \mathrm{L})$ [15]. In a UK survey on two rivers an increase in estrone concentration was measured due to the discharge of sewage treatment works [11]. In one of the rivers the estrone concentration profile downstream clearly followed the profile of estrone concentration of the plant effluent. Further, estrogens have also been found in sediments on the ocean floor surrounding sewage outfalls [18]

Micropollutants are an increasing health threat due to the accumulation of persistent organic pollutants in the environment. The increasing abundance of a vast range of pollutants in waterways is causing con technologies are required to effectively eliminate such micropollutants. Activated carbon adsorption and coagulation are generally less effective due to the low concentrations of micropollutants and and coagulation are generally less effective due to the low concentrations of micropollutants and
competitive sorption between natural organic matter and micropollutants $[19,20]$. Other competitive sorption between natural organic matter and micropollutants $[19,20]$. Other
alternatives are advanced oxidation, although those processes produce an array of unknown byproducts with an often equal or higher toxicity $[1,21,22]$. Membrane technology is used predominantly for micropollutant control in water and wastewater treatment as well as in water reuse applications. Nanofiltration (NF) and reverse osmosis (RO) are the most suitable membrane processes for micropollutant control while more porous processes such as microfiltration (MF) and ultrafiltration (UF) cannot retain such small molecules. However, NF and RO (MF) and micropollutants is reported as erratic and not predictable from molecular weight of micropollutants [23-39].

In the last decade micropollutant breakthrough curves have been reported in the NF literature [23-25]. The important role of micropollutant sorption to polymeric materials used in water treatment has become apparent. This paper provides a state-of-the art review of the mechanisms and parameters responsible for micropollutant retention and sorption to membrane polymers in water treatment applications. Limitations of current knowledge and potential new approaches to find such interaction mechanisms are outlined. Better understanding of these interactions will enable the reduction of adsorption onto polymeric membranes if it is an unwanted 
Schäfer, A.I. ; Semião, A. ; Akanyeti, I. (2011)

Micropollutant sorption to membrane polymers, Advances in Colloid and Interface Science, 'Membrane Separation and Colloid Science' invited special issue paper (accepted 09/2010). doi:10.1016/j.cis.2010.09.006

mechanism that alters removal efficiency. Alternatively, new water treatment processes may result that take advantage of such sorption mechanisms for enhanced removal of micropollutants. For example, polymeric materials that are highly effective in adsorption can be used as novel membrane materials. Such novel materials may incorporate specific selectivity for target micropollutants.

While the mechanisms described in this paper apply to most micropollutants to varying degrees, depending on chemical characteristics of micropollutants, the group of estrogens was selected for this review to allow a better focus on sorption mechanisms.

\section{Micropollutant Characteristics: the Group of Estrogens}

The molecular structure and other characteristics of estrogens are summarised in Table 1. While to date no correlation between a single micropollutant characteristic and membrane retention and sorption could be identified, the characteristics contribute to various interaction mechanisms. Estrone, estradiol and estriol are natural estrogens which are derived from cholesterol and commonly found in excreta of humans and animals. Testosterone and progesterone, also manufactured by a mammal body are steroid hormones. There are several non-steroidal chemicals manufactured by a mammal body are steroid hormones. There are several non-steroidal chemicals synthetically manufactured which can interact with estrogen receptors such as ethinylestradiol, mestranol, diethylstilbestrol. Endocrine disrupting chemicals (EDCs, also referred to as hormonally active agents), are substances that disrupt the physiological function of endogenous hormones by acting like hormones in the endocrine system [26]. Examples of EDCs are contraceptive pill compounds, plasticizers, pesticides, and many other chemicals.

\section{[Table 1]}

Chemical characteristics ultimately determine treatability and sorption of micropollutants. A major difficulty in removing such micropollutants from water is not only the small concentration in which they occur and are physiologically active, but also their small size or molecular weight (MW). The MW of the hormones is very similar, varying between 268 and $315 \mathrm{~g} / \mathrm{mol}$. According to their MW these compounds are expected to be retained by NF and RO while they are too small for retention by MF and UF.

The $\mathrm{pK}_{\mathrm{a}}$ shows the acid dissociation constant at which the hormones lose a hydrogen atom and become negatively charged. The hormones that have a phenolic hydroxyl group all dissociate in the same $\mathrm{pH}$ range; between 10.2 and 10.5. At the $\mathrm{pH}$ above the $\mathrm{pK}_{\mathrm{a}}$, charge repulsion between the negatively charged hormone and the negatively charged membrane is expected to occur.

The Log $K_{\mathrm{OW}}$ parameter measures the hydrophobicity of the hormones by partitioning between octanol and water. As a general rule of thumb, compounds with $\log \mathrm{K}_{\mathrm{OW}}>2.5$ are expected to accumulate in solid phases instead of being soluble in the aqueous phase. The Log $\mathrm{K}_{\mathrm{OW}}$ values for the hormones described in Table 1 are above 2.5 (up to 5.1). Therefore hormones are expected to interact with the membranes by hydrophobic interactions [27, 28].

Estrogen solubility in water is reasonably low $(0.3$ to $441 \mathrm{mg} / \mathrm{L})$ with significant variability in published data. Dipole moments give an indication on the polarity of the molecules and vary from 1.6 to 4.6 Debye. The molecules with larger difference between positive and negative electrical charges have a higher dipole moment values [29]. Dipole moments of the molecules are important considering that considerable attractive interactions may occur because of the alignment of one dipole molecule with another [30].

Other characteristics considered have been molecular shape and size [31-34]. Van der Bruggen et al. [31] showed that molecular weight (MW) is a good indicator of NF and RO retention compared to other molecular sizes such as Stokes diameter. In general, the bigger the molecular size, the higher the retention [31-33]. Kiso et al. [35] obtained a clear increase of retention with increase of molecular size (such as molecular width, molecular mean size, and molecular weight) for alcohols and saccharides. However in a later study [36] this clear trend with molecular width was only obtained for one of the NF membranes used and not for the other 3 membranes. Molecular shape can be exploited to prepare molecular imprints in polymers to create specific sorption characteristics.

Proton donor and acceptor characteristics are further characteristics that may affect interaction with polymers, in particular the ability to form hydrogen bonds. H-bonding has been attributed to play a predominant factor in the transport of estrogens in biological systems [37-42]. The hormones such as E1, E2 and DES all possess a phenol group which is electron-rich [43] and can therefore have the potential to form $\pi-\pi$ bonding with electron deficient phenyl groups [30] of the polymers.

Such micropollutant characteristics affect the retention and sorption by membranes and this will be examined in the following sections.

\section{Retention of Micropollutants by Polymeric Membranes}

The retention of micropollutants such as estrogens varies significantly with membrane process type, membrane characteristics, operating conditions, specific micropollutant characteristics and membrane fouling. In MF and UF micropollutants such as estrogens are not usually retained due to the small molecular weight. However, retention can be increased through association of micropollutants with retained matter or hybrid processes such as powdered activated carbon coupled with MF or UF [44-46].

In NF and RO retention of estrogens can vary from 0 to near $100 \%$ depending on the membrane (see Figure 1). Such variation invites a thorough investigation of retention mechanisms to achieve a more reliable and predictable performance.

\section{[Figure 1]}

Both size and charge are important and the mechanisms of micropollutant removal can be summarised as illustrated in Figure 2. Any non-retained micropollutants will penetrate into the polymer matrix, while those retained are accumulating in the boundary layer (membrane surface).

Steric Exclusion is a first mechanism that is essentially a sieving principle (Figure 2A) determined by micropollutant size. Pollutants larger than the membrane pore size are normally retained because of a sieving effec particles $[17,24,31,47-53]$. While this mechanism is thought to be well established in membrane filtration, unexpected results have been observed with retention of some micropollutants considerably lower than expected based on molecular weight $[34,54]$. Some have attributed such variation to molecular length and shape $[37,55,56]$ although Van der Bruggen et al. [31] concluded that correlation of retention with size parameters other than MW (e.g. Stokes diameter) was only a marginal improvement.

[Figure 2]

Charge and Donnan exclusion are further mechanisms of exclusion of solutes by membranes. Those describe the repulsion between a charged solute and a charged membrane (Figure 2B). Naturally, this process is well understood for inorganic salts, while organic acids, (Figure 2B). Naturally, this process is well understood for inorganic salts, while organic acids, macromolecules and micropollutant behaviour needs to be better understood. Micropollutants of
similar or smaller size than the membrane pores can be retained due to charge repulsion between the
membrane polymer and the micropollutant [23,24, 31, 53, 57-62]. This mechanism is applicable for charged micropollutants only and hence speciation is very important. Speciation is micropollutan specific and can change depending on water characteristics as well as solute-solute interactions that result in ligand formation and complexation. Most estrogens that have a phenolic hydroxyl $(\mathrm{OH})$ group dissociate above $\mathrm{pH} 10.25$ to 10.5 . In consequence those estrogens are uncharged at neutral 
Schäfer, A.I. ; Semião, A. ; Akanyeti, I. (2011)

Micropollutant sorption to membrane polymers, Advances in Colloid and Interface Science, 'Membrane Separation and Colloid Science' invited special issue paper (accepted 09/2010).

doi:10.1016/j.cis.2010.09.006

$\mathrm{pH}$ while charge interactions occur above $\mathrm{pH} 10$. Retention of estrone has been shown to increase at $\mathrm{pH}>10$ due to the dissociation of the hormone $[57,63]$

The charge of membrane polymers can be measured using streaming potential methods and is generally negative at neutral to high $\mathrm{pH}$ for common $\mathrm{NF}$ and $\mathrm{RO}$ membranes [41, 59,63-65]. Such charge results from chemical modification of polymer surfaces. Actual charge depends on membrane polymer characteristics, functional group content as well as solution chemistry such as $\mathrm{pH}$, ionic strength and attachment of ions. The increase of ionic strength, for example, decreases $\mathrm{pH}$, ionic strengt he contaminan (i.e. Donnan exclusion mechanism) [60, 66-68]. Nghiem et al. [60] showed that the addition of calcium ions decreased retention of charged pharmaceuticals even more dramatically than an increase in $\mathrm{NaCl}$ concentration. This can be attributed to a more effective charge shielding by calcium ions due to its divalent charge compared to monovalent sodium ions.

To measure estradiol retention by $\mathrm{NF}$ as a function of $\mathrm{pH}$, crossflow experiments were conducted. A stainless steel system with a $2.5 \mathrm{~L}$ feed tank with a cooling jacket of $0.09 \mathrm{~m}^{2}$ and a high pressure pump (P200 from Hydra-Cell, UK) was connected to a flat sheet membrane cell (MMS, Switzerland) Temperature was monitored in the retentate by a temperature indicator (WTM (MMS, Swizerland). Ter Pt 100-0-6 from Condustrie-Metag, Germany). The cooling jacket is connected to a temperature controlled bath (WK 700, Lauda). A back pressure regulator from (KPB1N0A415P60000, Swagelok, UK) allows the pressurization of the system up to $130 \mathrm{bar}$. The pressure is monitored in both feed and retentate side of the membrane cell with two pressure transducers ( $\mathrm{S}$ model, Swagelok). The membrane cell hosts a membrane of $46 \mathrm{~cm}^{2}$ with a flow channel width of $2.5 \mathrm{~cm}$, length of $19.1 \mathrm{~cm}$ and height of $0.1 \mathrm{~cm}$. A flow meter was inserted between the pump and the membrane cell to allow for the control of the flow rate (M2SSPI from Hydrasun, UK). Datalogging was set-up (DAQ 55 Omega, UK) allowing for the control of membrane cell inlet and outlet pressure, feed flow rate and temperature. All cross-flow experiments were carried out with an initi ( 0.5 or $2 \mathrm{~L} / \mathrm{min}$ (Reynolds number of 740 and 2800 , respectively), $11 \mathrm{bar}, 24^{\circ} \mathrm{C}$ until the membrane was saturated and steady state was reached. For experiments at $\mathrm{pH} 11$, the $\mathrm{pH}$ was adjusted with $1 \mathrm{M} \mathrm{NaOH}$ (Fisher Scientific, UK)

Higher retention at $\mathrm{pH} 11$ compared to $\mathrm{pH} 7$ is illustrated in Figure 3B where at high $\mathrm{pH}$ charge repulsion occurs between the dissociated estradiol and the negatively charged membrane. Retention at pH 11 stabilises at 85\%, while at $\mathrm{pH} 7$ retention is only 60\% (Figure 3B). However, concentration in the feed decreases gradually, while the permeate concentration increases until equilibrium observed to change with time, which is not expected if size and charge are predominant retention mechanisms. The permeate concentration shows a breakthrough curve which evidences that this unsteady trend of concentrations is caused by adsorption of estradiol onto the NF membrane.

\section{[Figure 3]}

Adsorption (Figure 2C) and subsequent sorption diffusion (Figure 2D) has indeed been confirmed for micropollutants by various polymeric membranes [23, 25-28, 30, 32-34, 36, 40, 56, 68, 78-83]. Nghiem and Schäfer [25] have measured such a breakthrough curve for estrogens at $100 \mathrm{ng} / \mathrm{L}$ using a technique with radiolabelled micropollutants. Adsorption however can be affected by solution chemistry. As shown in Figure 3, adsorption is lower at high $\mathrm{pH}$ due to charge repulsion by solution chemistry. As shown in Figure 3, adsorption is lower at high $\mathrm{pH}$ due to charge repulsion
(Figure 3C). This is clearly reflected in an increased estradiol mass flux at $\mathrm{pH} 7$ (Figure 3D). The same trends were obtained by Hu et al. [63] and McCallum et al. [57]. The observation reflects that of a breakthrough curve that is commonly observed in adsorption or ion exchange processes. Notably such adsorption is higher when the retention is lower (Figure 3C), indicating that penetration of micropollutants into the polymer matrix enhances sorption, while sorption itself may also decrease retention.
Solute-solute interactions and fouling can make the determination of actual retention mechanisms difficult and adsorption in particular is often confused with membrane deposi formation or concentration polarization phenomena. During filtration the deposits of retained materials as well as fouling change the membrane surface and hence possible charge, steric and sorption interactions. In addition, changes in retention over time or in different water matrices may occur due to solute-solute interactions (Figure $2 \mathrm{E}$ ) as well as micropollutant-fouling laye ultrafiltration membranes $[45,46,69]$ or cause desorption of adsorbed micropollutants making retention mechanisms in real waters a very complex affair.

Given that adsorption is a very common observation in membrane filtration of micropollutants this mechanism will be investigated systematically in this review to gain a better understanding. In the following section transport models will be summarised before returning to adsorption in more mechanistic detail.

\section{Micropollutant Transport Models for Membrane Filtration}

Descriptions of solute transport in RO membranes were originally given by the irreversible thermodynamic model [70,71]. The membrane was treated like a black box, no membrane structural or electrical parameters were acquired and scarce information about the transport mechanisms inside the membrane could be obtained [72]

The solution-diffusion model was proposed where it considers that each permeant dissolves in the membrane and is transported by diffusion due to its gradient in chemical potential through a non-porous membrane [72]. The solute flux is independent of permeation pressure while the solvent flux increases proportionally to it. Retention must therefore increase with pressure. This was confirmed for metals, some ions and saccharides, namely uranium, raffinose, sodium, magnesium and calcium $[66,68,73,74]$.

For NF membranes, there is some debate about the existence of discrete pores. In this case the solution-diffusion model is incomplete and a convection term should be included that takes account of solute transport through membrane pores. The retention of uncharged solutes in $\mathrm{NF}$ membranes can be described with the hydrodynamic model [75] previously described. The transport takes into account diffusion and hindered convection, caused by the difference between solute size and pore size. For charged solutes such as ions or organic acids, the addition of the membrane and and pore size. For charged solutes such as ions or organic acids, the addition of the membrane and
ion electrochemical potential derives in the extended Nernst-Planck equation [73]. This last model ion electrochemical potential derives in the extended Nernst-Planck equation [73]. This last model
not only allows determining the same parameters as the hydrodynamic model but also allows the not only allows determining the same parameters as the hydrodyna
determination of the effective membrane charge density $[54,76,77]$.

Generally, both the solution diffusion model and the hydrodynamic model describe an increase of retention for solutes with pressure. However, for some micropollutants the opposite trend is observed, e.g. with hormones [50,78], pesticides [53, 61], volatile organic carbon (VOC such as chloroform) [47], endocrine disrupting chemicals (EDCs) such as nonylphenol (NP) [79] and pharmaceuticals [61] where retention decreases with pressure. It is thought that the interaction of micropollutants with the membrane polymer plays an important role [54] and contributes to the reduced retention at higher pressure. However this phenomenon is not directly linked with the ratio between the solute and pore radius $\left(\lambda=\mathrm{R}_{\text {solute }} / \mathrm{R}_{\text {pore }}\right)$. It could be argued that for $\lambda<1$, the solutes can penetrate the membrane and be less retained. However, for nanofiltration of $\mathrm{Na}_{2} \mathrm{SO}_{4}$, glycerine and glucose as examples of non-adsorbing compounds with $\lambda<1$, retention increases with increase of pressure $[73,80]$. This trend is not always verified for micropollutants with $\lambda<1$ [78]. When pores physically exist the issue of steric hindrance or size exclusion is obvious. However, considering a pure steric hindrance model is not accurate in the case of dense materials and adsorbing solutes [54]. Solute retention depends not only on solute size but also on adsorption and chemical organic characteristics such as hydrophobicity, as well as convection and diffusion mechanisms [81].

Adsorption of micropollutants to the membrane polymer is usually not taken into account in micropollutant retention models $[54,58,59,82]$. In consequence, retention, permeate 
Schäfer, A.I. ; Semião, A. ; Akanyeti, I. (2011)

Micropollutant sorption to membrane polymers, Advances in Colloid and Interface Science, 'Membrane Separation and Colloid Science' invited special issue paper (accepted 09/2010).

doi:10.1016/j.cis.2010.09.006

concentration and mass flux are therefore often wrongly determined. Retention, in particular, is commonly overestimated when based on size. The interaction that exists between adsorbing micropollutants and the membrane was incorporated in the hydrodynamic model for NF using an affinity concept [83]. Although retention was predicted well and increased with permeate flux for the adsorbing contaminants, for other contaminants, retention decreased with increase of flux [78]. Furthermore, a simplified approach to model the retention of several micropollutants in NF has been developed [82]. For some micropollutants, such as xeno-estrogens, high membrane adso has been developed [82]. For some micropollutants, such as xeno-estrogens, high mentane adsorption occurred and in consequence no permeate concentration was measurable. This prevents the application of this model, which does not take adsorption into account, for solutes that interact with membranes. For other solutes, diffusion only transport closely matched the measured retention. In another study the irreversible thermodynamic model was used as a basis to understand if convection or diffusion were the predominant contributor in the solute (DBP and halogenated solvents) permeate flux for NF and RO membranes [84]. This proved problematic for adsorbing compounds and the membranes had to be presaturated to achieve steady state. When reaching steady state proved to be impossible as for the case of trichloroethene, no conclusions could be drawn.

Interestingly, adsorption has been considered in a modified sorption-diffusion model for RO that added adsorption induced flux decline to pressure [85]. Results confirm flux decline due to the
adsorption of the organic compounds on the membrane polymer through specific adsorption (e.g. hydrogen bonding). Organics may compete with water for adsorption sites and decreasing water content on the membrane and flux. Further, this model described the transient permeate concentration behaviour more adequately that the previous model which considered steady state conditions of water and solute flux across the membrane, by assuming adsorption-diffusion transport of organics in the membrane polymer. Shortfalls of this model remain (i) the inapplicability to NF due to a missing convection element, and (ii) the common absence of a flux reduction element due to micropollutant sorption $[85,86]$. This outlines the need for retention ( the solutemembrane interactions. Some attempts have been made in this direction using artificial neura networks. The principal component analysis method (quantitative structure relations or QSR) has been developed to obtain a model that describes retention as a function of the contaminants most important variables (e.g. molecular width and depth) by nanofiltration membranes $[55,56]$ and the NF membrane characteristics such as roughness or active layer thickness [32]. Limitations of such models are the validity for certain boundary conditions only, and while simple in nature, they cannot replace the understanding of fundamental mechanisms.

A further complexity that is not yet theoretically predictable is the behaviour of micropollutant mixtures. In real waters many micropollutants are found together with other organics such as effluent or natural organic matter. This can result in solute-solute interactions [87]. When organic matter is present in solution enhanced retention is generally obtained for micropollutants $[45,52,58,61,78,88-91]$ due to partitioning of the micropollutants into the retained organics $[92$, 93]. Higher adsorption is obtained, possibly on both membrane and organic matter layer that is formed on the membrane surface $[62,63,88,89,94]$. According to some studies, the presence of a humic acid fouling layer renders the membrane more hydrophobic, enhancing estrone adsorption $[63,89]$. However, this increased sorption may be attributable to interactions between humic acid and micropollutants more so than increased hydrophobicity. In contrast, a decrease in micropollutant adsorption may occur when natural oranics and micropollutants compete for micte for (n) or between micropollutants and other organics at much higher concentrations. In single solution the sorption is higher than in mixtures and retention lower. Competition decreases the retention when compared to a single micropollutant solution [92, 100], while retention of these adsorbing compounds is enhanced when their adsorption is decreased [86]. This shows the close relationship between adsorption phenomena and retention of micropollutants. Several models to predict the amount adsorbed on a membrane for mixtures based on the amount adsorbed with only one compound has also been developed [101].
While solute retention in NF and RO is reasonably well understood, the retention of adsorbing micropollutants cannot currently be adequately described. Results obtained with pristine and saturated membranes often show diametrically opposed results making the interpretation of literature difficult. Understanding of adsorption mechanisms and transient adsorption will be instrumental to fully incorporate adsorption phenomena into membrane models successfully. In consequence this adsorption will be investigated below.

\section{Micropollutant Sorption in Membrane Filtration}

Sorption by membrane polymers occurs across the range of available processes and polymers. In this section a number of examples are provided from pressure driven membrane processes and electrodialysis. Observation of micropollutant sorption to membrane polymers is a recent phenomenon. This is presumably due to the development of analytical techniques that facilitate the detection of molecules in nanogram quantities of pollutants of very low concentration. facilitate the detection of molecules in nanogram quantities of pollutants of very low concentration.
However, such sorption would be a very common occurrence for many pollutants albeit often not However, such sorption would be a very common occurrence for many pollutants albeit often not
measurable. Sorption of organics is well recognised as a conditioning film for subsequent biofilm attachment. Micropollutants accumulate in biofilms. However, the understanding of the impact of estrogens on growth of such biofilms or their degradation by biofilms is not yet established [102, $103]$.

While porous membranes such as MF and UF do not retain micropollutants, the polymer surface may adsorb significant amounts. This has resulted in the removal of estrone by a $0.2 \mu \mathrm{m} \mathrm{MF}$ polypropylene membrane of more than $95 \%$ [104] which can only be attributed to adsorption. Other
examples showed $>34 \%$ of $17 \beta$ estradiol adsorption on a ultrathin polyimide UF membrane [105] examples showed $>34 \%$ of $17 \beta$ estradiol adsorption on a ultrathin polyimide UF membrane [105]
whereas $36 \%$ and $30 \%$ retention of bisphenol A was observed in other studies $[46,106]$. UF whereas $36 \%$ and $30 \%$ retention of bisphenol A was observed in other studies [46, 106]. UF
membranes were used to recover $6 \alpha$-methylprednisolone from cell suspensions, and 27\% and $31 \%$
of hormone was adsorbed on two different MWCO UF polysulphone membranes [107]. Jermann et of hormone was adsorbed on two different MWCO UF polysulphone membranes [107]. Jermann et
al. [69] have shown low estradiol retention by a hydrophilic UF membrane, while a hydrophobic membrane showed very high retention with a gradual decrease as the polymer saturated with estradiol. Higher retention was attributed to organic matter fouling while Neale and Schäfer quantified the contribution of organic matter - micropollutant interactions in the absence significant sorption for a hydrophilic membrane [108]. This illustrates the complexity of such interactions.

Naturally, the majority of micropollutant sorption results have been published in NF, while comparison can be very interesting. High adsorption of the hormones estradiol, progesterone and testosterone on both a UF (sulphonated polyethersulphone coated with polyimide) and NF (polyamide) membranes was observed, while surprisingly estrone did not adsorb [96]. Adsorption of estradiol was lower for NF than UF; for a delivered mass of estradiol of $1 \mu \mathrm{g} / \mathrm{cm}^{2}$, the UF membrane adsorbed about $0.5 \mu \mathrm{g} / \mathrm{cm}^{2}$ and the NF adsorbed about $0.2 \mu \mathrm{g} / \mathrm{cm}^{2}$ [95]. Adsorption occurs on different membrane layers and alters if static adsorption (no pressure/filtration) as occurs on to filtrotion) as A polyamide membrane was studied in a stirred cell system without pressure. Adsorption of all hormones varied between 0.20 and $0.35 \mathrm{ng} / \mathrm{cm}^{2}$ for a feed concentration of $10 \mu \mathrm{g} / \mathrm{L}$ [52]. Adsorption of $100 \mathrm{ng} / \mathrm{L}$ estrone to two NF membranes made of cellulose acetate (CK, MWCO 560 $\mathrm{g} / \mathrm{mol}$ ) and polyamide (DL, MWCO $490 \mathrm{~g} / \mathrm{mol}$ ) resulted in a decrease in feed concentration due to sorption of $20 \%$ and $65 \%$, respectively. According to McCallum et al. [57] adsorption of estradiol occurred mainly in the polysulphone layer compared to the polyamide layer, where samples of different stages of membrane manufacturing were used. However the layers used in this study were provided from the manufacturing process of a different membrane (NE 70 instead of NF 270). Williams et a. [85] on the of procers of a different benzene and 2-chlorophenol on the polyamide layer when compared to the polysulphone layer benzene and 2-chlorophenol on the polyamide layer when compared to the
showing that interactions are micropollutant and membrane material specific. 
Charge repulsion reduces adsorption (see Figure 3C) and this is confirmed in Figure 4 for a number of different membranes. A stirred-cell was used for experiments at 5 bar, a feed concentration of $100 \mathrm{ng} / \mathrm{L}$ of estrone (E1) and estradiol (E2), and $1 \mathrm{mM} \mathrm{NaHCO}_{3}$ and $20 \mathrm{mM} \mathrm{NaC}$ for the TFC-S and TFC-SR2 membranes [109, 110]. The X20 experiment was carried out at $10 \mathrm{bar}$ [25]. Hu et al. [63] used a cross-flow system with $1 \mathrm{mM} \mathrm{NaHCO} 3,8 \mathrm{mM} \mathrm{NaCl}, 14$ bar, $100 \mathrm{ng} / \mathrm{L}$ estradiol with the DL membrane until the membrane was saturated. Retention varies depending on membrane type and while this is constent from $\mathrm{pH} 3$ to 10 , above $\mathrm{pH} 10$ both retention on mentran adsorption decease dratically is can all attributed to the fact that these membranes were not at equilibrium and in consequence, the retention measured is misleading. In the presence of synthetic urine, ethinylestradiol adsorbed to the $\mathrm{NF} 270$ membrane in the order of $3.6 \mu \mathrm{g} / \mathrm{cm}^{2}$ for a very high feed concentration of $3 \mathrm{mg} / \mathrm{L}(10 \mu \mathrm{M})$ and an effective membrane area of $0.0028 \mathrm{~m}^{2}$ [93]. High adsorption of several hormones in batch experiments in the following increasing order of adsorption were measured: X20 ( $M W C O<200 \mathrm{Da}$ polyamide $)>\mathrm{TS} 80($ MWCO <200 Da, polyamide $)>\mathrm{NF} 270($ MWCO 400 Da, polyamide $)>\mathrm{UE} 10$ (MWCO $10000 \mathrm{Da}$, polysulphone) [111]. MWCO and material effects cannot be distinguished.

[Figure 4]

Adsorption is lowest for the membrane with highest retention (X20) indicating that 'pore size' may play an important role in adsorption. In order to investigate the relationship between such 'pore size' and adsorption, a number of membranes were characterised in terms of molecular weight cut off (MWCO) and pore radius. The pore radius and the ratio membrane active laye thickness/porosity was determined for each membrane using the hydrodynamic model $[75,76]$ with neutral solutes (methanol, dioxane, xylose and dextrose). This model assumes perfect cylindrica pores of identical pore radius, solutes of spherical shape and that retention of the solutes only occurs through steric exclusi drodynamic model to the real solute retention variation with permeate flux. The same methodology described by Nghiem et al. [54] was adopted for the BW30, NF90 and NF270 characterisation using a cross-flow system. The TFC-SR2 and TFC-SR3 characteristics were determined with the same method in stirred-cells [112]. The active surface area (membrane surface area including pore surface area) was estimated with an average of active layer thickness of the membranes from literature [113-117] and summarised in Table 2. With the membrane active layer thickness, porosity can be obtained and therefore the internal surface area of the membrane active layers can be calculated. Since no active layer thickness has been published for the TFC-SR3 membrane an average value of reported thicknesses for the TFC-S and TFC-SR2 membranes was determined [113, 118-120].

\section{[Table 2]}

The equivalent sphere radius of estradiol was calculated with the Stokes-Einstein equation Crossflow experiments were carried out with the same system as described for Figure 3. Retention of estradiol decreased with increasing pore radius above the estimated radius of estradiol of $0.4 \mathrm{~nm}$ from about $80 \%$ to $30 \%$. Mass adsorbed increased with pore radius for both the membrane area (as per sheet size) as well as per estimated total membrane area available to sorption. Sorption is lower when regarded as per available internal surface area sugesting that adsorption occurs internally and when regarder and increases with increasing available area. It should be noted here that this area only considers the internal area of the active layer (polyamide) and not the polysulphone supporting layer. More work is required to differentiate between those materials systematically.

[Figure 5]

Sorption to membrane polymers is not unique to NF and RO. In fact, sorption to electrodialysis (ED) membranes can be significantly higher than for other membranes. Pronk et al.
[121] used polyethersulphone electrodialysis membranes with an effective surface area of $49 \mathrm{~cm}^{2}$ per sheet in an ED stack of two cell pairs to recover salts from urine containing ethinylestradiol (EE2). The result showed that approximately $230 \mu$ mole of EE2 was adsorbed on the membrane when $400 \mu$ mole of the hormone is added in initial urine solution at a high concentration of $10 \mu \mathrm{M}$ (about $3 \mathrm{mg} / \mathrm{L}$ ) [121]. Taking into account the molecular weight of ethinylestradiol the adsorption was estimated as $139 \mathrm{\mu g} \mathrm{EE} / \mathrm{cm}^{2}$ where the initial EE2 mass added into solution was as high as 119 m. Basiak [122] has $119 \mathrm{mg}$. Bansiak [122] has measured the adsorption of different hormones to electrodialysis high as $1.2 \mathrm{ng} / \mathrm{cm}^{2}$.

[Figure 6]

Such enhanced adsorption can be attributed to very thick membranes in ED as compared to an active layer thickness in NF or RO. In addition, the effective area is very high due to the internal porosity observed in ED. Electrodialysis membranes can be classified in three groups regarding their size of clusters in swollen state. These groups are homogeneous, microheterogeneous and heterogeneous. The 'pore size' of homogenous Nafion ED membranes is about $1 \mathrm{~nm}$ whereas Nafion 117 has a pore diameter of about $6 \mathrm{~nm}$ [123]. Eurodia/Neosepta electrodialysis membranes have a very low molecular weight cut off (350 Da MWCO) [124]. Khulbe et al., states that dialysis have a very low molecular weight cut off ( $350 \mathrm{Da}$ MWCO) [124]. Khulbe et al., states that dialysis
membranes have a pore diameter changing between 2 and $5 \mathrm{~nm}$ [125]. In contrast, several hollow fibre electrodialysis membranes were imaged by AFM and TEM and the results showed that pore diameter at the inner surface was $10.5 \mathrm{~nm}$ and $12.9 \mathrm{~nm}$ for polyester-polymer alloy (PEPA) and polysulphone polyvinylpirrolidone (PS+PVP) materials, respectively [126]. This indicates a nanoporous structure throughout the membrane with a thickness of hundreds of $\mu \mathrm{m}$, which illustrated the role such an internal area plays for micropollutant adsorption- or absorption.

\section{Micropollutant Sorption by active Polymer Surface Area}

The mechanisms of micropollutant sorption to membrane polymers is to date not well understood. Steinle-Darling et al. [127] described two mechanisms of micropollutant sorption; a first one being adsorption to the membrane surface, and a second being internal absorption into the membrane pore structure. Solvation in the membrane and diffusion within are processes that lead from adoption to absortion. While this process is coneptully resonable, the reality in vailo membrane processes may be more complex. In porous membranes, for example, the available membrane surface area will extend into the material and it becomes debatable where adsorption ends and absorption starts. A further complication is the material characteristics of composite membranes that consist of support layers and active layers of different material, thickness, pore size and porosity. This will alter the available surface area considerably even without considering the heterogeneity of such materials. It is difficult, if not impossible, to determine the internal polymer surface area available for micropollutant sorption.

To investigate this effect of surface area systematically, adsorption of estrone (E1) to polystyrene nanoparticles separated by UF membranes was investigated (see Figure 7). Regenerated cellulose ultrafiltration (UF) membranes with a polypropylene support layer of 1,3,5 kDa MWCO supplied by Millipore (Bedford, US) were used. Those membranes were chosen as sorption is minimal and fouling does not occur at those small MWCOs [128-130] for the chosen nanoparticles during the given experiments. Polystyrene nanoparticles with a size range of $46 \mathrm{~nm}$ to $3 \mu \mathrm{m}$ were purchased from Polysciences, Inc. (Eppelheim, Germany). The experiments were conducted with stainless steel stirred cells in which solution operated at $300 \mathrm{rpm}$ with a magnetic stirrer Radiolabelled $\left[2,4,6,7-{ }^{3} \mathrm{H}\right]$ estrone $(2.45 \mathrm{TBq} / \mathrm{mmol})$ with a radioactive concentration of 37 $\mathrm{MBq} / \mathrm{mL}$ was purchased from Perkin Elmer (Beaconsfield, UK). Prior to the experiments, the membranes were compacted for 30 minutes and pure water flux determined. $15.7 \mathrm{mg} / \mathrm{L}$ of 
Schäfer, A.I. ; Semião, A. ; Akanyeti, I. (2011)

Micropollutant sorption to membrane polymers, Advances in Colloid and Interface Science, 'Membrane Separation and Colloid Science' invited special issue paper (accepted 09/2010).

doi:10.1016/j.cis.2010.09.006

nanoparticles were added in $100 \mathrm{~mL}$ pure water solution and deposited on the surface of the membrane by filtering the solution through the membrane at 5 bar. Afterwards, $450 \mathrm{~mL}$ of stock solution was filtered by collecting 8 samples of $50 \mathrm{~mL}$ permeate samples until $50 \mathrm{~mL}$ of concentrate remained in the stirred cell.

\section{[Figure 7]}

Results indicate that adsorption of estrone (E1) decreases sharply with increase of particle size due to the reduced surface area of larger particles. Surface normalised sorption increases with
particle size which indicates that the available surface is not saturated. Increased sorption with the particle size which indicates that the available surface is not saturated. Increased sorption with the
lower MWCO membranes can be attributed to a longer contact time between micropollutants and the retained nanoparticles due to the lower flux. Clearly, sorption can be attributed to surface area when such a surface area can be calculated accurately which is the case for such spherical nanoparticles. Sorption is directly related to the available surface area and this has direct implications to sorption of membrane polymers. However, for generally very heterogeneous polymers, the determination of the actual surface area of a membrane polymer is very difficult if not impossible to determine accurately.

To evaluate such surface variability, the internal membrane surface area has been estimated as a function of pore size of cylindrical pores (Figure 8A-C) and voids between spherical grains (Figure 8D) with varying thickness and porosity. A membrane surface area of $100 \mathrm{~cm}^{2}$ was considered and equation (1) was used for perfectly shaped cylindrical pores to determine surface area from pore size, porosity and active layer thickness.

Total Area $=$ Surface Area + Internal Area $=W L(1-\varepsilon)+\frac{2 L W \varepsilon \delta}{r_{p}}$

Where $\mathrm{W}$ and $\mathrm{L}$ are the membrane width and length $(10 \mathrm{~cm})$ respectively, $\varepsilon$ is the membrane porosity, $\delta$ is the active layer thickness and $r_{p}$ is the pore radius.

For membranes made from spherical grains which is the case for some MF, UF and ED membranes, a cubic close packing of spherical grains was used and equation (2) shows the relationship between the surface area, active layer thickness and sphere radius.

$$
\text { Surface Area }=\frac{16 W L \delta \pi r_{\text {sphere }}{ }^{2}}{\left(2 \sqrt{\left.2 r_{\text {sphere }}\right)^{3}}\right.}
$$

Where $r_{\text {sphere }}$ is the sphere radius. This indicates a rapid increase of internally available surface area with decreasing pore size at similar porosity and a linear increase of this surface area with membrane thickness.

$$
\text { [Figure 8] }
$$

While such calculations can be carried out for conceptual or ideal membrane characteristics, the characterisation of pore size, membrane thickness and porosity (and in consequence internal pore area) of real membranes, in particular composite membranes used for NF is very difficult, if possible at all.

A range of characterisation tools exists for membrane characteristics such as porosity, pore size and active layer thickness. Active layer thickness can be measured by SEM [115, 131, 132], Rutherford Backscattering Spectrometry [131], TEM [133], as well as Impedance Spectroscopy Rutherford Backscattering Spectrometry [131], TEM [133], as well as Impedance Spectroscopy
[134]. Thickness of the active layer has been determined by Freger et al. [114, 133, 135] to be in the [134]. Thickness of the active layer has been determined by Freger et al. $[114,133,135]$ to be in the
order of $10-200 \mathrm{~nm}$ for NF and 200-350 nm for RO membranes of polyamide active layer. Uranyl nitrate staining of the active layer followed by transmission electron microscopy was used. The work illustrated how highly non-uniform polymer density and charged surface groups are distributed across the active polyamide layer. The densest part of the layer may be covered by an extensive surface roughness which makes the accurate determination of surface available for sorption extremely difficult. Surface roughness for three thin film composite NF membranes - with polyamide active layers - is shown in Figure 9. This image implies a very high surface roughness for TFC membranes.

Membrane surface roughness can be quantified by AFM [136-138]. Values for average roughness between 0.4 and $5 \mathrm{~nm}$ were reported, while some membranes show much higher values, $28 \mathrm{~nm}$ for NF90 [139] and $>60 \mathrm{~nm}$ for BW30 [140]. Surface roughness for cellulose acetate membrane supports have been reported as high as $17 \mathrm{~nm}$ [138]. Using such values AFM can be membrane supports have been reported as high as $17 \mathrm{~nm}$ [138]. Using such values AFM can be
used to estimate the surface area of membranes, where for a projection area of $100 \mu \mathrm{m}^{2}$ surface used to estimate the surface area of membranes, where for a projection area of $100 \mu \mathrm{m}^{2}$ surface
areas between 150 and $180 \mu \mathrm{m}^{2}$ were reported for an average surface roughness between 40 and 85 areas between 150 and $180 \mu \mathrm{m}^{2}$ were reported for an average surface roughness between 40 and 85 $\mathrm{nm}[141]$. It is possible that such figures are an underestimate when the internal membrane structure is considered accurately, the likely range of which is evident from Figure 8. Ultimately such values membrane while properties within the material remain unknown.

\section{[Figure 9]}

Positron annihilation spectroscopy (PAS) can be used to determine the top layer porosity [115]. A difference between the pore size of the top layer and support layer can be obtained indirectly, although no physical value of porosity was published. An evident increase in porosity is observed at the transition between the active layer to the more porous sub-layer. Porosity can however be determined experimentally. Several authors have used the hydrodynamic model [75] by filtrating neutral organic and inorganic solutes to obtain the pore radius, active layer thickness to porosity ratio $[54,76,77,142]$. With the knowledge of the thickness of the active layer (e.g. by p. using TEM), 0 ne be used to determine the number of pores and the pore radius of several commercially available membranes [143, 144]

Attempts to identify a discrete pore size of NF membranes by AFM resulted in estimates from 0.1 to $2 \mathrm{~nm}[139,145]$. While such methods are limited to pores visible from the membrane surface and the existence of discrete pores in nanofiltration is subject to ongoing controversy, the results obtained are in the same order of magnitude as effective pore sizes determined by other methods. As previously mentioned the hydrodynamic model can also be used to determine the membrane pore radius. As an illustration the pore radius obtained for the NF270, TFC-SR2 and NF90 were $0.42,0.52$ and $0.34 \mathrm{~nm}$ respectively (Table 2).

In addition to physical parameters of the membrane such as internal surface area and roughness, chemical characteristics of the micropollutant and of membrane polymers alter adsorption behaviour.

\section{Micropollutant Sorption by different Polymer Materials}

The observation of micropollutant sorption to polymeric materials is not new and early observations were made of interactions with laboratory equipment. For example, Petri dishes (PVC) were found to adsorb significant amounts of hormones and results were verified with grinded PVC [146]. One study established that polystyrene plastic ware adsorbed $38 \%$ and $43 \%$ of $17 \beta-$ estradiol and progesterone, respectively [147], while another study reported that the majority of parathyroid hormone sorbed to borosilicate glass tubes, polycarbonate and cellulose nitrate. Sorption to polypropylene tubes was lower and equilibrium was reached within 4 hours [148]

Packaging materials equally have an adsorption capacity for hormones. Results using granular materials found very high adsorption capacities for polystyrol $\left(6 \mathrm{ng} / \mathrm{cm}^{2}\right)$, for glass $(18$ $\mathrm{ng} / \mathrm{cm}^{2}$ and $105 \mathrm{ng} / \mathrm{cm}^{2}$ depending on the glass type), for polypropylene $\left(60 \mathrm{ng} / \mathrm{cm}^{2}\right)$, for polyethylene (PE, $75 \mathrm{ng} / \mathrm{cm}^{2}$ ), for Lupolen (low density polyethylene, $180 \mathrm{ng} / \mathrm{cm}^{2}$ ) and for Cellidor 
Schäfer, A.I. ; Semião, A. ; Akanyeti, I. (2011)

Micropollutant sorption to membrane polymers, Advances in Colloid and Interface Science, 'Membrane Separation and Colloid Science' invited special issue paper (accepted 09/2010).

doi:10.1016/j.cis.2010.09.006

(Celluloseacetobutyrat; more than $420 \mathrm{ng} / \mathrm{cm}^{2}$ ) [149]. While concentration values were not provided the high adsorption most likely indicates a relatively high concentration of contaminants used.

Such observations are not unique to hormones. Volatile chemicals (trichloroethene and tetrachloroethene) to polyethylene (PE) was competitive for hydrophobic micropore spaces in the polymer. Such competition is anticipated when solutes of similar polarity and size compete for a limited number of sites, and smaller micropore spaces dominate sorption interactions [150] Adsorption of hydrophobic chemicals, PCBs, DDE and NP (nonlyphenol) to polypropylene (PP) Adsicter (PP) marine resin pellets collected for the Japanese coss was reported to vary from 4-117 ng/g, 0.16 $3.1 \mathrm{ng} / \mathrm{g}, 0.13-16 \mu \mathrm{g} / \mathrm{g}$ for $\mathrm{PCB}$, DDE and NP, respectively. Determination of the specific surface area of PP pellets was estimated as $25 \mathrm{~cm}^{2} / \mathrm{g}$ and surface specific adsorption results were $4.7 \mathrm{ng} / \mathrm{cm}^{2}$, $0.12 \mathrm{ng} / \mathrm{cm}^{2}, 0.36 \mu \mathrm{g} / \mathrm{cm}^{2}$ for PCB, DDE and NP, respectively [151]. Significant sorption of hydrophobic endocrine disrupting compounds to porous polysulphone beads was reported [152].

Sorption has also been observed for filters used in sample preparation resulting in significan losses of analytes. Different types of filter materials were tested for estradiol adsorption and the results showed that cellulose acetate and cellulose nitrate adsorbed the most estradiol compared to glass fibre and paper materials [149]. Adsorption of up to 50\% of feed estradiol concentration on a cellulose acetate filter was observed [153].

Sorption interactions are exploited for analytical purposes which is commonly the case in chromatography as well as sample preparation. Solid phase extraction (SPE) is used for the concentration of analytes in samples. The most widely used SPE sorbents for micropollutants are alkyl-bonded silicas (C18 silica, C2 silica), copolymer sorbents such as cross-linked polystyrene divinylbenzene, and hydrophilic lipophilic balanced polymers. Each has specific contaminan applications [154, 155]. C18 resins and other polymeric sorbents have been used in several studies separate or in combination for purification and determination of pesticides, estrogens and progestogens with SPE [156-158]. Solid phase micro-extraction (SPME) sorbs a fraction of other dissolved molecules. Polyacrylate has been used for the detection of estrogens in water and their interactions with organic matter [87, 159]. Polydimethylsiloxane (PDMS), divinylbenzene (DB), polyacrylate (PA), as well as Carboxen (CAR; a carbon molecular sieve) and Carbowax (CW; polyethylene glycol) are other commonly used coating polymers for SPME of organics [160].

Similar sorption phenomena are observed in other water treatment applications that involve polymer interfaces. For example, magnetic ion exchange resin (MIEX) developed for enhanced natural organics removal, sorbs significant amounts of uncharged micropollutants such as estrogens [161]. The resin has a macroporous polyacrylate shell with quaternary ammonium functional groups for ion exchange.

These results highlight an affinity of certain organic solutes for polymeric materials and a strong material dependence on interactions. While it is no surprise that membrane polymers adsorb micropollutants, the mechanisms of micropollutant adsorption onto polymers are to date scarce not well understood and hence a systematic investigation is required. For this reason a range of polymers (see Table 3) commonly used for membrane materials has been selected for preliminary investigation and the very novel results are subsequently presented in this review.

\section{[Table 3]}

While differences in sorption are significant for different polymers, a complete lack of understanding exists as to why this is the case. It is a hypothesis that once adsorption facilitates micropollutant diffusion through the polymer matrix even if larger than 'pores'. This is driven to some extent, but not solely, by a concentration gradient and may explain some of the incomplete retention observed at larger scale. This mechanism is poorly understood and hence neither predictable, nor controllable. Other factors that contribute to sorption may be the ability of a micropollutant to interact specifically with polymer functional groups, Gibbs free energy of the localised environment as well as other factors.
Proprietary material modification by membrane manufacturers make this challenging if not mpossible and it is hence worthwhile studying such interactions with 'pure' polymer materials Inconsequence sorption of estradiol (E2) was determined for a range of polymers produced from pure pellets by grinding to a size of $<500 \mathrm{~mm}$ as well as ground membrane polymers (see Figure 10). Figure $10 \mathrm{~A}$ and $\mathrm{B}$ present mass of estradiol adsorbed per mass of polymer for the different polymers, while in Figure 10C and $\mathrm{D}$ the results are normalised for the particle size as measured by electron micoscopy and ant shape. Polymers (

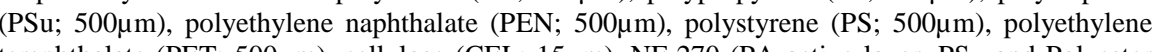

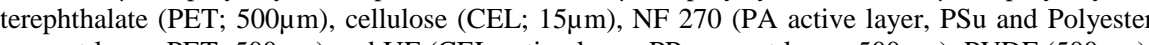

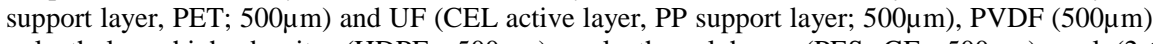

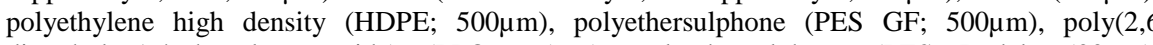
dimethyl 1,4-phenylene oxide) (PPO; $\sim 5 \mu \mathrm{m}$ ), polyethersulphone (PES Radel; 500 $\mu \mathrm{m}$ ), polysulphone UDEL (PSu U; 500 $\mu \mathrm{m}$ ) and poly(methyl methacrylate) (PMMA; 36 $\mu \mathrm{m}$ ).

[Figure 10]

PSu, PP, HDPE, PA, PS, PET, PEN and PES were purchased from Goodfellow (Huntingdon, UK) in the form of 2-3 mm granules. PSu UDEL and PVDF were obtained from Solvay (Brussels, Belgium) in granular form and CEL, PMMA and PPO were purchased from Sigma Aldrich (Gillingham, UK) in powder form. Polymers in granular form were grinded to a size of $0.5 \mathrm{~mm}$ with Retsch Ultra Centrifugal Mill ZM 200 (Leeds, UK), in three stages using sieves with $1.00,0.75$ and $0.50 \mathrm{~mm}$ openings. Radiolabelled $\left[2,4,6,7-{ }^{3} \mathrm{H}\right] 17 \beta$-estradiol $(3.15 \mathrm{TBq} / \mathrm{mmol})$ from Perkin Elmer (Beaconsfield, UK) was used to prepare $60 \mathrm{~mL}$ of $100 \mathrm{ng} / \mathrm{L}$ solutions. 2.5g of each polymer was added into separate estradiol solutions and the solutions mixed in a Certomat BS1 UHK-25 shake $\mathrm{mL}$ syringes at certain time intervals and filtered through $0.7 \mu \mathrm{m}$ glass microfibre filters (Fisher Loughborough, UK) which was placed in Millipore Swinnex filter support (Ireland). Based on the results of preliminary experiments where glassfibre filters were chosen due to their lowest sorption of estradiol, after the third sample filtration, the filter reached saturation and the adsorption calculated was due to polymer adsorption. The activity in initial and filtrate samples were counted in triplicate using a Beckman LS 6500 liquid scintillation counter (Fullerton, USA) by mixing 0.5 $\mathrm{mL}$ samples with $3.5 \mathrm{~mL}$ of Ultima Gold LLT liquid scintillation liquid (Beaconsfield, UK) in 20 $\mathrm{mL}$ glass scintillation vials. Experiments were stopped after about 8000 minutes.

Results indicate that sorption of estradiol to polymer particles is a surface phenomenon for polymers with very strong affinities (Figure 10). This is demonstrated from very rapid kinetics as is the case of polyamide (PA). The high sorption to PA is confirmed with a similar result for the NF membrane material (NF270), a thin film composite with a PA active layer. Another highly sorbing polymer is polyethersulphone (PES) although in this case adsorption kinetics are not as quick. Either the phenomenon is not restricted to the polymer surface or due to weaker interactions, the adsorption process is slower. Nonetheless, this study gives a very good indication of the affinity of estradiol to different types of polymers. However given the uncertainties of particle shape and size distribution, it is not possible to distinguish between affinities of polymers that adsorb less. It should be noted that the observed results correlate well with experimental observations to date in NF where active layer consists of PA and presented above. Surprising is the low affinity of polymers that are considered hydrophobic, such as polyvinylidene fluoride (PVDF).

It should be noted here that the polymers used are raw materials. In membrane manufacturing such polymers are processed to have a morphology and porosity. Further, proprietary chemical modifications take place that introduce surface functionality not shown by the primary polymer.

Chemical characteristics, such as the molecular structure and functional groups of the active layer of membranes can be studied with ATR-FTIR [115], while atomic concentration percentages 
Schäfer, A.I. ; Semião, A. ; Akanyeti, I. (2011)

Micropollutant sorption to membrane polymers, Advances in Colloid and Interface Science, 'Membrane Separation and Colloid Science' invited special issue paper (accepted 09/2010).

doi:10.1016/j.cis.2010.09.006

of $\mathrm{C}, \mathrm{O}, \mathrm{N}$ and $\mathrm{S}$ can be obtained by using X-ray photoelectron spectroscopy XPS [134]. Hydrophobicity of polymers is measured as contact angle [162] while for micropollutants hydrophobicity is expressed as octanol water partition coefficient ( $\left.\mathrm{K}_{\mathrm{OW}}\right)$

In general the more hydrophobic a compound is, the more it is expected to adsorb onto a surface in contact with water because this requires less free energy compared to forming a "cavity" in the water phase [163]. In the case of membrane polymers higher the hydrophobicity has also been attributed to more adsorption $[58,60,95,111,164]$. For example, Boussu et al. [164] obtained a clear trend of increasing adsorption with increasing hydrophobicity of the organic compound such as phenylalanine. Two of the more hydrophobic PES membranes adsorbed much higher quantities as phenylalanine. Two of the more hydrophobic PES membranes adsorbed much higher quantities
compared to the phenylalanine membrane. However, some exceptions exist where highly hydrophobic micropollutants adsorbed very little onto NF polyamide or polyethersulphone membranes.

In the specific case of hormones, Dudziak and Bodzek [165] showed that adsorption and retention was not related with hydrophobicity for two different NF membranes (polyamide and cellulose acetate). DES, the most hydrophobic hormone (see Table $1, \log \mathrm{K}_{\mathrm{OW}}$ 5.07) adsorbed the least for both membranes studied, while the cellulose acetate membrane adsorbed less than the polyamide membrane. This can be explained by the fact that cellulose has practically no binding
capacity for steroids $[166,167]$. In the presence of natural organic matter a clear trend between capacity for steroids $[166,167]$. In the presence of natural organic matter a clear trend between
hydrophobicity and adsorption of trace contaminants (e.g. hormones, analgesics, antibiotics, etc.) on polyamide active layers is not clear either [96]

In terms of retention of micropollutants by membrane polymers, generally, higher micropollutant hydrophobicity results in lower retention [34, 164, 168]. However, several studies showed that membrane rejection of organic compounds (including hormones, pharmaceuticals, pesticides, etc.) varies greatly for similar hydrophobicities [33, 36, 91, 169]. In the case of nonphenylic pesticides retention increased with increase of hydrophobicity for NF membranes with PA or PES active layers [100]. Comerton et al. [169] obtained a higher retention by a PA NF active layer for the DES hormone compared to the other hormones, despite DES being much more hydrophobic (see Table 1). Kim et al. [38] equally obtained higher retention values for more hydrophobic contaminants such as disinfection by-products and chlorinated solvents.

As can be seen in Figure 11 for contact angle and Figure 12 for $\log \mathrm{K}_{\mathrm{OW}}$, this does not always correlate affinity with retention successfully. The reason being that hydrophobicity fails to identify specific material affinities between polymers and micropollutants [83]. It is therefore important to understand underlying adsorption mechanisms in more detail.

\section{[Figure 11]}

[Figure 12]

One of the main reasons why so little is known about membrane adsorption is the difficulty in obtaining specific material characteristics for membrane polymers. Some characterisation data is available, for example gas adsorption analysis conducted on PE showed that there was almost no internal porosity and the polymer had a small surface area compared to other particles. Nevertheless, partitioning was stated to play an important role in sorption atrazine and trichloroethene to PE which is a strongly hydrophobic polymer [150, 170]. Other author atributed a slow diffusion of the hydrophobic compounds into PP granules to slow sorption [171]

When looking at more detailed chemical characteristics, results in Figure 10 showed that the absence of both double bonded oxygen and ring structure reduce sorption of estradiol. However, the PE based polymers such as PET and PEN do not readily adsorb estradiol despite having these functional groups. The difference in interaction might lie in the fact that PE have oxygen in the form of ketone groups $(=\mathrm{O})$ and PES have oxygen in the form of sulphonyl groups $\left(-\mathrm{SO}_{2}\right)$. In the case of polyamide, despite the absence of a ring structure hydrogen bonding interactions are possible between the amine and the ketone group. Interestingly, polyamide (nylon 6) is used in thin layer chromatography (TLC) to separate organic compounds that are able to hydrogen bond. In consequence, polyamide had been used for separation of phenols, carboxylic acids, amino acid derivatives, steroids, quinines, aromatic nitro compounds, nucleotides, bile pigments and pesticides $[172,173]$. Beyond chromatography, such principles are used for sample pre-treatment such as solid phase extraction. Hydrophobic effect, dipole-dipole, dipole-induced dipole and dispersive interactions, hydrogen bonding and ionic interactions play role for the interactions between the analytes and the sorbent [174], with hydrophobic interaction being the most widely used sorption mechanism in solid phase extraction [175].

Hydrophobicity is clearly not the decisive factor in determining adsorption indicating that other types of interactions (supramolecular interactions such as hydrogen bonding and $\pi-\pi$ stacking) may play an important role.

\section{Supramolecular Mechanisms in Micropollutant Sorption by Polymers}

Adsorption is dependent on the membrane material used [23, 100], the contaminant and its properties such as hydrophobicity $[58,60,95,96,100,111,176]$, acid dissociation constant $[95,96$, 111] and aptitude to hydrogen bond or engage in other supramolecular interactions.

A summary of such interactions, as described in supramolecular chemistry and adapted to possible micropollutant interactions is shown in Figure 13. A further example of such interactions are carbon based nanomaterials that have a high capacity for hydrophobic, electrostatic and $\pi-\pi$ interactions [177]. In fact, Ji et al. [178] proposed that $\pi-\pi$ interactions were responsible for the sorption of sulphonamide antibiotics on multiwalled carbon nanotubes. As many of such interactions are not yet well understood and very difficult to quantify, the occurrence and their extent of those interactions remains speculative.

\section{[Figure 13]}

The mechanism of possible hydrogen bonding interactions for a number of polymers is illustrated in Figure 14. In addition to H-bonding, $\pi-\pi$ interactions are a possible mechanism to be considered. The difference between the $\pi$ densities of the adsorbent and the corresponding adsorbate determines the stability of the $\pi-\pi$ interaction. $\pi$ density is determined by electron rich and deficient aromatic fragments [179].

\section{[Figure 14]}

Returning to characteristics summarised in Table 3 and results in Figure 10 a number of observations can be made. $\pi$ - $\pi$ interactions and strong hydrophobic interactions are involved in the sorption mechanisms of methylene and phenyl groups to hypercrosslinked polystyrene [180]. Davankov (2003) [179] states that $\pi-\pi$ interactions between the hypercrosslinked polystyrene and the substances with $\pi$-systems of electrons such as aromatic rings, carboxyl groups and alike governs the retention mechanisms in HPLC application with non-polar solvents. In fact, hypercrosslinked polystyrene has a strong $\pi$-electron donating-accepting ability in non-polar organic solvents. This ability results in high sorption capacity of compounds which contain aromatic $\pi$-systems or function Sorbents used in SPE with phenyl groups (such as polystyrene divinlybenzene) have the capacity to interact with steroids through $\pi-\pi$ interactions. The number and positioning of phenyl groups in this phase determine the level of $\pi-\pi$ interactions and the sorption capacity. It was suggested that the $\pi-\pi$ interaction between the phenyl phase and the steroid occurs when the double bonds of steroid and phenyl group overlap [182]. Similar phenomena are likely when estrogens are in contact with membrane polymers which may explain the strong sorption of estrogens by polystyrene, although the main mechanism for polystyrene sorption is hydrophobic interactions (Figure 10A). The aromatic ring in polystyrene is electron neutral, while the benzene rings in estrone and estradiol are 
Schäfer, A.I. ; Semião, A. ; Akanyeti, I. (2011)

Micropollutant sorption to membrane polymers, Advances in Colloid and Interface Science, 'Membrane Separation and Colloid Science' invited special issue paper (accepted 09/2010). doi:10.1016/j.cis.2010.09.006

electron rich. For $\pi-\pi$ interactions to occur an electron poor aromatic group is required in the polymer. In consequence $\pi-\pi$ interaction is anticipated to not be a major contributing mechanism in this case. The extent and precise type of contribution is not possible to determine with currently available tools.

Polyamide is the strongest adsorbent of the polymers tested which can be explained by its quite polar nature and ability to act as both hydrogen acceptor and donor. Results obtained in estrogen sorption to the polymer confirm the observations in membrane filtration. In contrast, PVDF is considered a hydrophobic polymer but is known to dislike interactions with either with hydrophobic or hydrophilic compounds. The adsorption to PVDF (Figure 10B) is indeed relatively low.

Polysulphone (Figure 10A) and polyethersulphone radel (PES R, Figure 10B) have similar functional groups but the hormone sorption onto these polymers is very different. This difference can be explained by the fact that polysulphone has more diluted functional groups in the structure compared to PES R. The sulphone group of PES R makes the polymer polar and available for $\mathrm{H}-$ bonding.

Although cellulose has a high capacity for H-bonding it does not like to H-bond with other molecules which is confirmed with the estrogen results (Figure 10A). It does, however, interact with its own functional groups.

Clearly, polymer-hormone interactions cannot be explained by only one interaction mechanism. While the qualitative and quantitative measurement of such interactions is currently limited by the availability of suitable characterisation tools, the above results indicate that such interactions ay indeed play an important role in sorption. Supramolecular interactions such as hydrogen bonding involving micropollutants and polymers are weaker in nature and quantification of both interaction energy and identification of specific mechanisms is currently limited to molecular dynamics simulations. This limits the predictive capacity of membrane models that accurately predict both retention and sorption.

\section{Conclusions \& Outlook}

The aim of this review has been to illustrate the impact of adsorption of micropollutant retention in membrane filtration and to elucidate mechanisms of micropollutant adsorption to membrane polymers. Estrogens were used as an example of such micropollutants. Interaction mechanisms are governed, most likely, by hydrophobic as well as solvation effects and interplay of molecular and supramolecular interactions such as hydrogen bonding, $\pi$-cation/anion interactions, $\pi-\pi$ stacking, ion-dipole and dipole-dipole interactions. The extent of which each mechanism contributes is naturally dependent on micropollutant and polymer characteristics. Besides such interactions, the available surface area of membrane polymers is the most important parameter. interactions, the available surface area of membrane polymers is the most important parameter.
Challenges remain in the areas of; (i) qualitative and quantitative determination of chemical interactions between polymers and micropollutants, (ii) accurate characterisation of membrane material properties and internal surface area available for sorption, (iii) the integration of sorption phenomena into membrane retention models.

Systematic investigations are required to identify and quantify both relative contributions and strength of such interactions and develop suitable surface characterisation tools. This is a difficult endeavour given the complexity of systems, the possibility of several interactions taking place simultaneously and the generally relatively weak forces involved. Further developments in supramolecular chemistry to understand and measure complex interactions, surface analytical tools supramolecular chemistry to understand and measure complex interactions, surface analytical tools
to quantify such interactions, molecular dynamics modelling and the availability of well defined membrane materials (such as carbon nanotube materials) will contribute significant progress in this field. With such enhanced understanding the design of membranes able to remove micropollutants over the range of characteristics will be possible.

\section{Acknowledgments}

Howard Colquhoun (University of Reading) and Arno Kraft (Heriot-Watt University) have contributed with useful discussions on polymer - micropollutant interactions and supramolecular chemistry. Alanna Stacey Campbell and Chris Jeffree have assisted with polymer characterisation. Laura Banasiak has provided results of micropollutant interactions with electrodialysis membranes. Bart van der Bruggen (KU Leuven) and Rudolf Graf (Berghof) have supplied membrane polymers while membrane samples were donated by Dow Chemicals, Koch, and Millipore. Nigel Staples while membrane samples were donated by Dow Chemicals, Koch, and Millipore. Nigel Staples
from Retsch assisted with the loan of the Ultra Centrifugal Mill and Laura Richards is thanked for from Retsch assisted with the loan of the Ultra Centrifugal Mill and Laura Richards is thanked for
NF90 and BW30 membrane characterisation results. Funding for Andrea Semiao and Ime Akanyeti is provided through a School of Engineering/DTA stipend and a RSC/EPSRC Analytical Science Studentship, respectively.

\section{References}

[1] Schwarzenbach, R. P., Escher, B. I., Fenner, K., Hofstetter, T. B., Johnson, C. A., von Gunten, U. \& Wehrli, B. Science 2006; 313: 1072-1077

[2] Gabriel, F. L. P., Routledge, E. J., Heidlberger, A., Rentsch, D., Guenther, K., Giger, W., Sumpter, J. P. \& Kohler, H.-P. E. Environmental Science \& Technology 2008; 42: 6399 6408

[3] Tyler, C. R., Jobling, S. \& Sumpter, J. P. Critical Reviews in Toxicology 1998; 28: 319361

[4] Younes, M. Chemosphere 1999; 39: 1253-1257

[5] Safe, S. H. Environmental Health Perspectives 2000; 108: 487-493

[6] Jobling, S., Nolan, M., Tyler, C. R., Brighty, G. \& Sumpter, J. P. Environmental Science Jobling, S., Nolan, M., Tyler, C. R., Brig
\& Technology 1998; 32: 2498-2506

[7] Zuccato, E., Calamari, D., Natangelo, M. \& Fanelli, R. Lancet 2000; 355: 1789-1790

[8] Schultz, M. M. \& Furlong, E. T. Analytical Chemistry 2008; 80: 1756-1762

[9] Körner, W., Bolz, U., Süßmuth, W., Hiller, G., Schuller, W., Hanf, V. \& Hagenmaier, H. Chemosphere 2000; 40: 1131-1142

[10] Baronti, C., Curini, R., D'Ascenzo, G., Di Corcia, A., Gentili, A. \& Samperi, R. Environmental Science \& Technology 2000; 34: 5059-5066

[11] Williams, R. J., Johnson, A. C., Smith, J. J. L. \& Kanda, R. Environmental Science \& Technology 2003; 37: 1744-1750

[12] Kolpin, D. W., Furlong, E. T., Meyer, M. T., Thurman, E. M., Zaugg, S. D., Barber, L. B. \& Buxton, H. T. Environmental Science \& Technology 2002; 36: 1202-1211

[13] Johnson, A. C. \& Sumpter, J. P. Environmental Science \& Technology 2001; 35: 46974703

[14] Batt, A. L., Kostich, M. S. \& Lazorchak, J. M. Analytical Chemistry 2008; 80: 5021-5030

[15] Rabiet, M., Togola, A., Brissaud, F., Seidel, J.-L., Budzinski, H. \& Elbaz-Poulichet, F. Environmental Science \& Technology 2006; 40: 5282-5288

[16] Heberer, T. Journal of Hydrology 2002; 266: 175-189

[17] Kim, S. D., Cho, J., Kim, I. S., Vanderford, B. J. \& Snyder, S. A. Water Research 2007; 41: 1013-1021

[18] Braga, O., Smythe, G. A., Schäfer, A. I. \& Feitz, A. J. Chemosphere 2005; 61: 827-833

[19] Pelekani, C. \& Snoeyink, V. L. Water Research 1999; 33: 1209-1219

[20] Quinlivan, P. A., Li, L. \& Knappe, D. R. U. Water Research 2005; 39: 1663-1673

[21] Andreozzi, R., Canterino, M., Marotta, R. \& Paxeus, N. Journal of Hazardous Materials 2005; 122: 243-250 
Schäfer, A.I. ; Semião, A. ; Akanyeti, I. (2011)

Micropollutant sorption to membrane polymers, Advances in Colloid and Interface Science, 'Membrane Separation and Colloid Science' invited special issue paper (accepted 09/2010). doi:10.1016/j.cis.2010.09.006

[22] Vogna, D., Marotta, R., Andreozzi, R., Napolitano, A. \& d'Ischia, M. Chemosphere 2004; 54: 497-505

[23] Kimura, K., Amy, G., Drewes, J. \& Watanabe, Y. Journal of Membrane Science 2003 221: 89-101

[24] Kimura, K., Amy, G., Drewes, J. E., Heberer, T., Kim, T.-U. \& Watanabe, Y. Journal of Membrane Science 2003; 227: 113-121

[25] Nghiem, L. D. \& Schäfer, A. I. Environmental Engineering Science 2002; 19: 441-451

[26] Colborn, T., Dumanoski, D. \& Myers, J. P. Our stolen future: are we threatening our fertility, intelligence, and survival? A scientific detective story. London: Penguin Books Ltd: 1997

[27] Jones, O. A. H., Voulvoulis, N. \& Lester, J. N. Crit. Rev. Env. Sci. Technol. 2005; 35: 401-427

[28] Rogers, H. R. Science Of The Total Environment 1996; 185: 3-26

[29] Suggs, J. W. Organic Chemistry. Barron's Collage Review Series, Inc: 2002

[30] Steed, J. W. \& Atwood, J. L. Supramolecular Chemistry. John Wiley\&Sons Ltd: 2009

[31] Van der Bruggen, B., Schaep, J., Wilms, D. \& Vandecasteele, C. Journal of Membrane Science 1999; 156: 29-41

[32] Libotean, D., Giralt, J., Rallo, R., Cohen, Y., Giralt, F., Ridgway, H. F., Rodriguez, G. \& Phipps, D. J. Membr. Sci. 2008; 313: 23

[33] Ozaki, H., N. Ikejima, Y. Shimizu, K. Fukami, S. Taniguchi, R. Takanami, R. R. Giri \& Matsui, S. Water Sci. Technol. 2008; 58: 73-81

[34] Kimura, K., Toshima, S., Amy, G. \& Watanabe, Y. Journal of Membrane Science 2004; 245: $71-78$

[35] Kiso, Y., Kon, T., Kitao, T. \& Nishimura, K. J. Membr. Sci. 2001; 182: 205

[36] Kiso, Y., Sugiura, Y., Kitao, T. \& Nishimura, K. Journal of Membrane Science 2001; 192 : 1

[37] Agenson, K. O. \& Urase, T. Separation and Purification Technology 2007; 55: 147-156

[38] Kim, T. U., Amy, G. \& Drewes, J. E. Water Sci. Technol. 2005; 51: 335-344

[39] Lin, Y.-L., Chiang, P.-C. \& Chang, E. E. Journal of Hazardous Materials 2007; 146: 20

[40] Lyko, S., Wintgens, T. \& Melin, T. Desalination 2005; 178: 95-105

[41] Schäfer, A. I., Nghiem, L. D. \& Waite, T. D. Environmental Science \& Technology 2003; 37: $182-188$

[42] Urmenyi, A. M., Poot, A. A., Wessling, M. \& Mulder, M. H. V. J. Membr. Sci. 2005; 259: 91

[43] Hostetler, E. D., Jonson, S. D., Welch, M. J. \& Katzenellenbogen, J. A. The Journal of Organic Chemistry 1998; 64: 178-185

[44] Chang, S., Waite, T. D., Ong, P. E. A., Schäfer, A. I. \& Fane, A. G. Journal of Environmental Engineering 2004; 130: 736-742

[45] Devitt, E. C., Ducellier, P. C., Cote, P. \& Wiesner, M. R. Water Research 1998; 32: 25632568

[46] Schäfer, A. I., Nghiem, L. D. \& Oschmann, N. Journal of Membrane Science 2006; 283: 233-243

[47] Ducom, G. \& Cabassud, C. Desalination 1999; 124: 115-123

[48] Raff, O. \& Wilken, R.-D. Desalination 1999; 122: 147-150

[49] Rosa, M. J. \& de Pinho, M. N. Journal of Membrane Science 1995; 102: 155-161

[50] Weber, S., Gallenkemper, M., Melin, T., Dott, W. \& Hollender, J. Water Science and Technology 2004; 50: 9-14

[51] Kosutic, K., Dolar, D., Asperger, D. \& Kunst, B. Separation and Purification Technology 2007; 53: 244-249

[52] Koyuncu, I., Arikan, O. A., Wiesner, M. R. \& Rice, C. Journal of Membrane Science 2008; 309: 94-101

[53] Berg, P., Hagmeyer, G. \& Gimbel, R. Desalination 1997; 113: 205-208
[54] Nghiem, L. D., Schäfer, A. I. \& Elimelech, M. Environ. Sci. Technol. 2004; 38: 18881896

[55] Yangali-Quintanilla, V., Sadmani, A., McConville, M., Kennedy, M. \& Amy, G. Water Research 2010; 44: 373-384

[56] Yangali-Quintanilla, V., Verliefde, A., Kim, T. U., Sadmani, A., Kennedy, M. \& Amy, G. Journal of Membrane Science 2009; 342: 251-262

[57] McCallum, E. A., Hyung, H., Do, T. A., Huang, C.-H. \& Kim, J.-H. Journal of Membrane Science 2008; 319: 38-43

[58] Nghiem, L. D., Schäfer, A. I. \& Elimelech, M. Separation Science and Technology 2005; 40: 2633-2649

[59] Nghiem, L. D., Schäfer, A. I. \& Elimelech, M. Environmental Science \& Technology 2005; 39: 7698-7705

[60] Nghiem, L. D., Schäfer, A. I. \& Elimelech, M. Journal of Membrane Science 2006; 286 $52-59$

[61] Xu, P., Drewes, J. E., Bellona, C., Amy, G., Kim, T.-U., Adam, M. \& Heberer, T. Water Environment Research 2005; 77: 40-48

[62] Xu, P., Drewes, J. E., Kim, T.-U., Bellona, C. \& Amy, G. Journal of Membrane Science 2006; 279: 165-175

[63] Hu, J. Y., Jin, X. \& Ong, S. L. Journal of Membrane Science 2007; 302: 188-196

[64] Childress, A. E. \& Elimelech, M. Journal of Membrane Science 1996; 119: 253-268

[65] Elimelech, M., Chen, W. H. \& Waypa, J. J. Desalination 1994; 95: 269-286

[66] Seidel, A., Waypa, J. J. \& Elimelech, M. Environmental Engineering Science 2001; 18 : 105-113

[67] Favre-Reguillon, A., Lebuzit, G., Foos, J., Guy, A., Draye, M. \& Lemaire, M. Industrial \& Engineering Chemistry Research 2003; 42: 5900-5904

[68] Favre-Reguillon, A., Lebuzit, G., Murat, D., Foos, J., Mansour, C. \& Draye, M. Water Research 2008; 42: 1160-1166

[69] Jermann, D., Pronk, W., Boller, M. \& Schäfer, A. I. Journal of Membrane Science 2009; Jermann, D $75-84$

[70] Spiegler, K. S. \& Kedem, O. Desalination 1966; 1: 311-326

[71] Peppas, N. A. \& Meadows, D. L. Journal of Membrane Science 1983; 16: 361-377

[72] Bitter, J. G. A. Transport Mechanisms in Membrane Separation Processes. New York: Plenum Press: 1991

[73] Bowen, W. R. \& Welfoot, J. S. In A. I. Schäfer, A. G. Fane and T. D. Waite (editors), Nanofiltration: Principles and Applications, Elsevier; 2005. Modelling the performance of nanofiltration membranes.

[74] de Pinho, M. N., Semião, V. \& Geraldes, V. Journal of Membrane Science 2002; 206 : 189-200

[75] Deen, W. M. AIChE Journal 1987; 33: 1409-1425

[76] Bowen, W. R., Mohammad, A. W. \& Hilal, N. Journal of Membrane Science 1997; 126: 91-105

[77] Combe, C., Guizard, C., Aimar, P. \& Sanchez, V. Journal of Membrane Science 1997; 129: 147-160

[78] Nghiem, L. D., Manis, A., Soldenhoff, K. \& Schäfer, A. I. Journal of Membrane Science 2004; $242: 37-45$

[79] Gallenkemper, M., Wintgens, T. \& Melin, T. Water Science and Technology: Water Supply 2003; 3: 321-327

[80] Bowen, W. R. \& Mukhtar, H. Journal of Membrane Science 1996; 112: 263-274

[81] Braeken, L., Van der Bruggen, B. \& Vandecasteele, C. The Journal of Physical Chemistry B 2006; 110: 2957-2962

[82] Cornelissen, E. R., Verdouw, J., Gijsbertsen-Abrahamse, A. J. \& Hofman, J. A. M. H. Desalination 2005; 178: 179-192 
Schäfer, A.I. ; Semião, A. ; Akanyeti, I. (2011)

Micropollutant sorption to membrane polymers, Advances in Colloid and Interface Science, 'Membrane Separation and Colloid Science' invited special issue paper (accepted 09/2010). doi:10.1016/j.cis.2010.09.006

[83] Verliefde, A. R. D., Cornelissen, E. R., Heijman, S. G. J., Hoek, E. M. V., Amy, G. L., Bruggen, B. V. d. \& van Dijk, J. C. Environmental Science \& Technology 2009; 43: 24002406

[84] Kim, T.-U., Drewes, J. E., Scott Summers, R. \& Amy, G. L. Water Research 2007; 41: 3977-3988

[85] Williams, M. E., Hestekin, J. A., Smothers, C. N. \& Bhattacharyya, D. Industrial \& Engineering Chemistry Research 1999; 38: 3683-3695

[86] Steinle-Darling, E. (2008) Rejection of trace organics - nitrosamines, perfluorochemicals, and others - via reverse osmosis and nanofiltration, PhD, Stanford University.

[87] Neale, P. A., Escher, B. I. \& Schäfer, A. I. Environmental Science \& Technology 2008; 42: $2886-2892$

[88] Agbekodo, K. M., Legube, B. \& Dard, S. Water Research 1996; 30: 2535-2542

[89] Jin, X., Hu, J. \& Ong, S. L. Water Research 2007; 41: 3077-3088

[90] Radjenovic, J., Petrovic, M., Ventura, F. \& Barceló, D. Water Research 2008; 42: 36013610

[91] Yangali-Quintanilla, V., Sadmani, A., McConville, M., Kennedy, M. \& Amy, G. Water Research 2009; 43: 2349-2362

[92] Plakas, K. V., Karabelas, A. J., Wintgens, T. \& Melin, T. Journal of Membrane Science 2006; 284: 291-300

[93] Pronk, W., Palmquist, H., Biebow, M. \& Boller, M. Water Research 2006; 40: 1405-1412

[94] Nghiem, L. D., Schäfer, A. I. \& Waite, T. D. Water Science and Technology 2002; 46 265-272

[95] Yoon, Y., Westerhoff, P., Yoon, J. \& Snyder, S. A. J. Environ. Eng. 2004; 130: 1460-1467

[96] Yoon, Y., Westerhoff, P., Snyder, S. A. \& Wert, E. C. Journal of Membrane Science 2006; 270: 88-100

[97] Nghiem, L. D. \& Coleman, P. J. Separation and Purification Technology 2008; 62: 709716

[98] Nghiem, L. D., Vogel, D. \& Khan, S. Water Research 2008; 42: 4049-4058

[99] Zhang, Y., Causserand, C., Aimar, P. \& Cravedi, J. P. Water Research 2006; 40: 3793 3799

[100] Kiso, Y., Nishimura, Y., Kitao, T. \& Nishimura, K. Journal of Membrane Science 2000; 171: 229-237

[101] Braeken, L., Boussu, K., Van der Bruggen, B. \& Vandecasteele, C. ChemPhysChem 2005; 6: $1606-1612$

[102] Flemming, H.-C. Water Sci. Technol. 1995; 32: 27

[103] Flemming, H.-C. \& Wingender, J. Nat Rev Micro 8: 623

[104] Chang, S., Waite, T. D., Schäfer, A. I. \& Fane, A. G. Environmental Science \& Technology 2003; 37: 3158-3163

[105] Yoon, Y., Westerhoff, P., Yoon, J. \& Snyder, S. A. J. Environ. Eng. 2004; 130: 1460-1467

[106] Lyko, S., Wintgens, T. \& Melin, T. Desalin. Water Treat. 2005; 178: 95-105

[107] Mateus, M. \& Cabral, J. M. S. Bioprocess. Biosyst. Eng. 1989; 4: 169-174

[108] Neale, P. A. \& Schäfer, A. I. Environmental Science and Technology in preparation;

[109] Nghiem, L. D., McCutcheon, J., Schäfer, A. I. \& Elimelech, M. Water Science and Technology 2004; 50: 215-220

[110] Nghiem, L. D., Schäfer, A. I. \& Waite, T. D. Water Science and Technology: Water Supply 2003; $3: 155-160$

[111] Comerton, A. M., Andrews, R. C., Bagley, D. M. \& Yang, P. Journal of Membrane Science 2007; 303: 267-277

[112] De Munari, A. \& Schäfer, A. I. Journal of Water Supply: Research and Technology Aqua 2010; 59: 152-162

[113] Nghiem, L. D. (2005) Removal of emerging trace organic contaminants by nanofiltration and reverse osmosis, $\mathrm{PhD}$, University of Wollongong.
[114] Freger, V. Environmental Science \& Technology 2004; 38: 3168-3175

[115] Boussu, K., Baerdemaeker, J. D., Dauwe, C., Weber, M., G. Lynn, K., Depla, D., Aldea, S., F. J. Vankelecom, I., Carlo, V. \& Bruggen, B. V. d. ChemPhysChem 2007; 8: 370-379

[116] Mänttäri, M., Pekuri, T. \& Nyström, M. Journal of Membrane Science 2004; 242: 107-116

[117] Tang, C. Y., Kwon, Y.-N. \& Leckie, J. O. Journal of Membrane Science 2007; 287: 146156

[118] Suzuki, T., Lu, Y., Zhang, W., Moore, J. S. \& Mariñas, B. J. Environmental Science \& Technology 2007; 41: 6246-6252

[119] Sharma, R. R. \& Chellam, S. Environmental Science \& Technology 2005; 39: 5022-5030

[120] Schäfer, A. I., Pihlajamäki, A., Fane, A. G., Waite, T. D. \& Nyström, M. Journal of Membrane Science 2004; 242: 73-85

[121] Pronk, W., Biebow, M. \& Boller, M. Environ. Sci. Technol. 2006; 40: 2414-2420

[122] Banasiak, L., Joan. (2009) Removal of Inorganic and Trace Organic Contaminants by Electrodialysis, PhD, Edinburgh University.

[123] Mauritz, K. A. \& Moore, R. B. Chem. Rev. 2004; 104: 4535-4586

[124] Perrin, B., Fiaty, K., Charcosset, C., Moueddeb, H., Couturier, R. \& Maïsterrena, B. Enzyme Microb. Technol. 2007; 40: 1604-1607

[125] Khulbe, K. C., Feng, C. Y. \& Matsuura, T. In (editors), Synthetic Polymeric Membranes, Springer Berlin Heidelberg; 2007. Pore Size, Pore Size Distribution, and Roughness at the Membrane Surface.

[126] Hayama, M., Miyasaka, T., Mochizuki, S., Asahara, H., Yamamoto, K.-i., Kohori, F., Tsujioka, K. \& Sakai, K. J. Membr. Sci. 2003; 219: 15-25

[127] Steinle-Darling, E., Zedda, M., Plumlee, M. H., Ridgway, H. F. \& Reinhard, M. Water Research 2007; 41: 3959-3967

[128] Costa, A. R. \& de Pinho, M. N. Journal of Membrane Science 2005; 255: 49-56

[129] Waite, T. D., Schäfer, A. I., Fane, A. G. \& Heuer, A. Journal of Colloid and Interface Science 1999; 212: 264-274

[130] Yuan, W. \& Zydney, A. L. Environ. Sci. Technol. 2000; 34: 5043-5050

[131] Mi, B., Coronell, O., Mariñas, B. J., Watanabe, F., Cahill, D. G. \& Petrov, I. Journal of Membrane Science 2006; 282: 71-81

[132] Boussu, K., Zhang, Y., Cocquyt, J., Van der Meeren, P., Volodin, A., Van Haesendonck, C., Martens, J. A. \& Van der Bruggen, B. Journal of Membrane Science 2006; 278: 418427

[133] Freger, V. Langmuir 2003; 19: 4791-4797

[134] Ariza, M. J., Cañas, A. \& Benavente, J. Surface and Interface Analysis 2000; 30: 425-429

[135] Freger, V., Gilron, J. \& Belfer, S. Journal of Membrane Science 2002; 209: 283-292

[136] Hilal, N., Al-Zoubi, H., Darwish, N. A., Mohamma, A. W. \& Abu Arabi, M. Desalination 2004; 170: 281-308

[137] Boussu, K., Van der Bruggen, B., Volodin, A., Snauwaert, J., Van Haesendonck, C. \& Vandecasteele, C. Journal of Colloid and Interface Science 2005; 286: 632-638

[138] Stamatialis, D. F., Dias, C. R. \& Norberta de Pinho, M. Journal of Membrane Science 1999; 160: 235-242

[139] Hilal, N., Al-Zoubi, H., Darwish, N. A. \& Mohammad, A. W. Desalination 2005; 177 : 187-199

[140] Simon, A., Nghiem, L. D., Le-Clech, P., Khan, S. J. \& Drewes, J. E. Journal of Membrane Science 2009; 340: 16-25

[141] Kwak, S.-Y. \& Woo Ihm, D. Journal of Membrane Science 1999; 158: 143-153

[142] Bowen, W. R. \& Mohammad, A. W. AIChE Journal 1998; 44: 1799-1812

[143] Kosutic, K., Dolar, D. \& Kunst, B. Journal of Membrane Science 2006; 282: 109-114

[144] Kosutic, K., Kastelan-Kunst, L. \& Kunst, B. Journal of Membrane Science 2000; 168 101-108

[145] Bowen, R. W. \& Doneva, T. A. Desalination 2000; 129: 163-172 
[146] Barksdale, A. W. Mycologia 1963; 55: 627-632

[147] Longman, S. M. \& Buehring, G. C. J. Tissue Cult. Meth. 1987; 10: 253-255

[148] Hamilton, J. W., Spierto, F. W., MacGregor, R. R. \& Cohn, D. V. J. Biol. Chem. 1971 246: 3224-3233

[149] Schicksnus, T. \& Müller-Goymann, C. C. Arch. Pharm. Pharm. Med. Chem 2000; 333: 66

[150] Li, J. \& Werth, C. J. Environ. Sci. Technol. 2001; 35: 568-574

[151] Mato, Y., Isobe, T., Takada, H., Kanehiro, H., Ohtake, C. \& Kaminuma, T. Environmental Science \& Technology 2000; 35: 318-324

[152] Zhao, C., Wei, Q., Yang, K., Liu, X., Nomizu, M. \& Nishi, N. Sep. Purif. Technol. 2004; 40: 297-302

[153] Neale, P. A., Pronk, W. \& Schäfer, A. I. Environ. Eng. Sci. 2009; 26: 1157-1161

[154] Bones, J., Thomas, K., Nesterenko, P. N. \& Paull, B. Talanta 2006; 70: 1117-1128

[155] Rodriguez-Mozaz, S., Lopez de Alda, M. J. \& Barceló, D. J. Chromatogr. A 2007; 1152: 97-115

[156] Kuch, H. M., Ballschmiter, K. \& Fresenius J. Anal. Chem. 2000; 366: 392-395

[157] Lacorte, S., Ehresmann, N. \& Barcelo, D. Environ. Sci. Technol. 1995; 29: 2834-2841

[158] Ternes, T. A., Stumpf, M., Mueller, J., Haberer, K., Wilken, R. D. \& Servos, M. Sci. Total Environ. 1999; 225: 81-90

[159] Neale, P. A., Escher, B. I. \& Schäfer, A. I. Science of The Total Environment 2009; 407: 1164-1173

[160] Dietz, C., Sanz, J. \& Cámara, C. J. Chromatogr. A 2006; 1103: 183-192

[161] Neale, P. A., Mastrup, M., Borgmann, T. \& Schäfer, A. I. Journal of Environmental Monitoring 12: 311-317

[162] Mulder, M. Basic principles of membrane technology. Dordrecht: Kluwer Academic Publishers: 1996

[163] Goss, K. \& Schwarzenbach, P. Journal of Chemical Education 2003; 80: 450-455

[164] Boussu, K., Vandecasteele, C. \& Van der Bruggen, B. Journal of Membrane Science 2008; $310: 51$

[165] Dudziak, M. \& Bodzek, M. Desalination 2009; 240: 236

[166] Ikeda, I., Tomari, Y. \& Sugano, M. J. Nutr. 1989; 119: 1383-1387

[167] Sundaravalli, O. E., Shurpalekar, K. S. \& Rao, M. N. J. Agric. Food. Chem. 1971; 19 116-118

[168] Braeken, L., Ramaekers, R., Zhang, Y., Maes, G., Bruggen, B. V. d. \& Vandecasteele, C. Journal of Membrane Science 2005; 252: 195

[169] Comerton, A. M., Andrews, R. C., Bagley, D. M. \& Hao, C. Journal of Membrane Science 2008; 313: 323-335

[170] Xing, B., Pignatello, J. J. \& Gigliotti, B. Environ. Sci. Technol. 1996; 30: 2432-2440

[171] Rice, M. R. \& Gold, H. S. Anal. Chem. 1984; 56: 1436-1440

[172] Deyl, Z. Separation Methods. Elsevier Science: 1984

[173] Fried, B. \& Sherma, J. Thin-layer chromatography. Marcel Dekker Inc: 1999

[174] Hennion, M.-C. J. Chromatogr. A 1999; 856: 3-54

[175] Schellen, A., Ooms, B., van de Lagemaat, D., Vreeken, R. \& van Dongen, W. D. J. Chromatogr. B 2003; 788: 251-259

[176] Yoon, Y., Westerhoff, P., Snyder, S. A., Wert, E. C. \& Yoon, J. Desalination 2007; 202: $16-23$

[177] Mauter, M. S. \& Elimelech, M. Environ. Sci. Technol. 2008; 42: 5843-5859

[178] Ji, L., Chen, W., Zheng, S., Xu, Z. \& Zhu, D. Langmuir 2009; 25: 11608-11613

[179] Davankov, V. A., Sychov, C. S., Ilyin, M. M. \& Sochilina, K. O. Journal of Chromatography A 2003; 987: 67-75

[180] Penner, N., Nesterenko, P., Ilyin, M., Tsyurupa, M. \& Davankov, V. Chromatographia 1999; 50: 611-620
[181] Sychov, C. S., Ilyin, M. M., Davankov, V. A. \& Sochilina, K. O. Journal of Chromatography 2004; 1030: 17-24

[182] Restek, (2005) Restek Application Note \#580020: Improved HPLC Analysis of Steroids Using Restek's Unique Allure ${ }^{\mathrm{TM}}$ Biphenyl Column, Retrieved 24.08.2010 from

[183] Kwon, J. H., Liljestrand, H. \& Katz, L. E. Environmental Toxicology and Chemistry 2006; 25: 1984-1992

[184] Ternes, T. A. \& Joss, A. Human pharmaceuticals, hormones and fragrances: the challenge of micropollutants in urban water management. London: IWA: 2006

[185] Hansch, C., Leo, A. \& Hoekman, D. Exploring QSAR: hydrophobic, electronic, and steric Hansch, C., Leo, A. \& Hoekman, D. Exploring QSAR: hydroph
constants. Washington, DC.: American Chemical Society: 1995

[186] Kubli-Garfias, C. Journal of Molecular Structure: THEOCHEM 1998; 452: 175-183

[187] Lai, K. M., Johnson, K. L., Scrimshaw, M. D. \& Lester, J. N. Environmental Science \& Technology 2000; 34: 3890-3894

[188] Banasiak, L. J. (2009) Removal of inorganic and trace organic contaminants by electrodialysis, $\mathrm{PhD}$, The University of Edinburgh.

[189] You, J., Zhao, H., Sun, Z., Suo, Y. \& Chen, G. Chromatographia 2009; 70: 45-55

[190] Lim, C. W., Fujiwara, S.-i., Yamashita, F. \& Hashida, M. Biological \& Pharmaceutical Bulletin 2002; 25: 361-366

[191] Duax, W. L., Griffin, J. F., Weeks, C. M. \& Korach, K. S. Environmental Health Perspectives 1985; 61: 111-121

[192] Bhandari, A., Surampalli, R. Y., Adams, C. D., Champagne, P., Ong, S. K., Tyagi, R. D. \& Zhang, T. C. Contaminants of Emerging Environmental Concern. ASCE: 2009

[193] Goodfellow, (2010) Technical Information, Retrieved 12 December 2009 from http://www.goodfellow.com/home.aspx?LangType=2057.

[194] Knoell, T., Safarik, J., Cormack, T., Riley, R., Lin, S. W. \& Ridgway, H. Journal of Membrane Science 1999; 157: 117-138

[195] Li, D. \& Neumann, A. W. Journal of Colloid and Interface Science 1992; 148: 190-200

[196] Ellison, A. H. \& Zisman, W. A. J. Phys. Chem. 1954; 58: 503-506

[197] Fujinami, A., Matsunaka, D. \& Shibutani, Y. Polymer 2009; 50: 716-720

[198] Pieracci, J., Crivello, J. V. \& Belfort, G. Journal of Membrane Science 1999; 156: 223 240

[199] Yoon, K., Hsiao, B. S. \& Chu, B. Polymer 2009; 50: 2893-2899

[200] Duca, M. D., Plosceanu, C. L. \& Pop, T. Polymer Degradation and Stability 1998; 61: 6572

[201] Khayet, M., Villaluenga, J. P. G., Godino, M. P., Mengual, J. I., Seoane, B., Khulbe, K. C. \& Matsuura, T. Journal of Colloid and Interface Science 2004; 278: 410-422

[202] Joubert, J. M., Krige, G. J. R. \& Borgin, K. Nature 1959; 184: 1561-1562

[203] Polyanskiy, M., (2008) Refractive index database, Retrieved 2009 December 12 from http://refractiveindex.info/.

[204] TexLoc, P., (2008) TexLoc Refractive Index of Polymers, Retrieved 12 December 2009 from http://www.texloc.com/closet/cl_refractiveindex.html.

[205] Neale, P. A. (2009) Influence of Solute-Solute Interactions on Membrane Filtration, University of Edinburgh. 
Schäfer, A.I. ; Semião, A. ; Akanyeti, I. (2011)

Micropollutant sorption to membrane polymers, Advances in Colloid and Interface Science, 'Membrane Separation and Colloid Science' invited special issue paper (accepted 09/2010). doi:10.1016/j.cis.2010.09.006

Table 1 Characteristics of micropollutant group of estrogens

\begin{tabular}{|c|c|c|c|c|c|c|c|c|c|}
\hline Compound & $\begin{array}{c}\text { Molecular } \\
\text { Formula }\end{array}$ & $\begin{array}{l}\text { CAS } \\
\text { No. }\end{array}$ & Mol Structure & $\begin{array}{c}\text { MW } \\
(\mathrm{g} / \mathrm{mol})\end{array}$ & $\begin{array}{l}\text { Solubility } \\
\text { in water } \\
(\mathrm{mg} / \mathrm{L})\end{array}$ & $\mathrm{pK}_{\mathrm{a}}$ & $\begin{array}{l}\text { Log } \\
\text { Kow }\end{array}$ & $\begin{array}{l}\text { Dipole } \\
\text { moment } \\
\text { (Debye) }\end{array}$ & $\mathrm{H}$ bond capacity \\
\hline Estradiol E2 & $\mathrm{C}_{18} \mathrm{H}_{24} \mathrm{O}_{2}$ & $50-28-2$ & & 272 & $3.6,82$ b,f,s & $10.23^{\circ}$ & 4.019 & $2.2^{\mathrm{h}}$ & $\begin{array}{l}\text { Strong } \mathrm{OH} \text { donor and } \\
\text { acceptor; } \pi \text { weak } \\
\text { acceptor (benzene) }\end{array}$ \\
\hline Estrone E1 & $\mathrm{C}_{18} \mathrm{H}_{22} \mathrm{O}_{2}$ & 53-16-7 & & 270 & 13,147 fl,s & $10.34^{\circ}$ & 3.139 & $\begin{array}{l}2.1, \\
3.36^{\mathrm{h}, \mathrm{o}}\end{array}$ & $\begin{array}{l}\text { Strong OH donor } \\
\text { and acceptor; Strong } \\
=0 \text { acceptor; } \pi \text { weak } \\
\text { acceptor (benzene) }\end{array}$ \\
\hline Testosterone T & $\mathrm{C}_{19} \mathrm{H}_{28} \mathrm{O} \mathrm{O}_{2}$ & $58-22-0$ & & 288 & $24,68^{m, s}$ & $17.4^{\mathrm{s}}$ & 3.329 & $3.53^{\mathrm{e}}$ & $\begin{array}{l}\text { Strong } \mathrm{OH} \text { donor and } \\
\text { acceptor; Strong =0 } \\
\text { acceptor; } \pi \text { weak } \\
\text { acceptor (benzene) }\end{array}$ \\
\hline Progesterone P & $\mathrm{C}_{2} \mathrm{H}_{3} \mathrm{O}_{2}$ & $57-83-0$ & & 315 & $5,8.8^{\mathrm{m}, \mathrm{s}}$ & NA & 3.879 & $\begin{array}{l}3.50 \\
4.588 .0\end{array}$ & $\begin{array}{l}\text { Strong }=0 \text { acceptor; } \\
\pi \text { weak acceptor } \\
\text { (benzene) }\end{array}$ \\
\hline Estriol E3 & $\mathrm{C}_{18} \mathrm{H}_{24} \mathrm{O}_{3}$ & $50-27-1$ & & 288 & $13,441^{1, n, s}$ & $\begin{array}{l}10.25 \\
10.4^{n, s}\end{array}$ & $2.60^{\prime}$ & $\begin{array}{l}1.71 \\
3.220, r\end{array}$ & $\begin{array}{l}\text { Strong } \mathrm{OH} \text { donor and } \\
\text { acceptor; } \pi \text { weak } \\
\text { acceptor (benzene) }\end{array}$ \\
\hline Mestranol ME2 & $\mathrm{C}_{21} \mathrm{H}_{26} \mathrm{O}_{2}$ & $72-33-3$ & & 310 & $0.3,3.5^{1, \mathrm{~s}}$ & - & $4.10^{\prime}$ & - & $\begin{array}{l}\text { Strong OH donor and } \\
\text { acceptor; Strong -O- } \\
\text { acceptor; } \pi \text { weak } \\
\text { acceptor (benzene) }\end{array}$ \\
\hline $\begin{array}{l}\text { Ethinylestradiol } \\
\quad \text { EE2 }\end{array}$ & $\mathrm{C}_{20} \mathrm{H}_{24} \mathrm{O}_{2}$ & $57-63-6$ & & 296 & $4.8,116^{r, s, 1}$ & $\begin{array}{l}10.25, \\
10.5^{n, s}\end{array}$ & $3.67^{\prime}$ & $2.64 r$ & $\begin{array}{l}\text { Strong } \mathrm{OH} \text { donor and } \\
\text { acceptor; } \pi \text { weak } \\
\text { acceptor (benzene) }\end{array}$ \\
\hline $\begin{array}{l}\text { Diethylstilbestrol } \\
\text { DES }\end{array}$ & $\mathrm{C}_{18} \mathrm{H}_{22} \mathrm{O}_{2}$ & $56-53-1$ & & 268 & $12 r$ & - & $5.07 r$ & $\begin{array}{l}1.62,2.2 \\
9, r\end{array}$ & $\begin{array}{l}\text { Strong OH donor and } \\
\text { acceptor; } \pi \text { weak } \\
\text { acceptor (benzene) }\end{array}$ \\
\hline
\end{tabular}

Table 2 Membrane characteristics determined experimentally and average active layer thickness obtained from the literature for five membranes used

\begin{tabular}{|lcccccc|}
\hline & $\begin{array}{c}\text { Pore } \\
\text { Radius } \\
\text { Rpore } \\
(\mathrm{nm})\end{array}$ & $\begin{array}{c}\text { Active Layer } \\
\text { Thickness } \\
\text { Porosity Ratio L } / \varepsilon \\
(\boldsymbol{\mu m})\end{array}$ & $\begin{array}{c}\text { Average } \\
\text { Active Layer } \\
\text { Thickness L } \\
(\mathrm{nm})\end{array}$ & $\begin{array}{c}\text { Total } \\
\text { Estimated } \\
\text { Surface Area } \\
\text { of Active } \\
\text { Layer }\left(\mathrm{cm}^{2}\right)\end{array}$ & Porosity & References \\
\hline BW30 & 0.32 & 6.01 & 250 & 2968 & 0.042 & {$[117]$} \\
\hline NF90 & 0.34 & 1.46 & 174 & 5529 & 0.119 & {$[113]$} \\
\hline TFC-SR3 & 0.38 & 1.59 & 114 & 1978 & 0.072 & $\begin{array}{c}{[118][119]} \\
{[120]^{\mathrm{a}}}\end{array}$ \\
\hline NF270 & 0.42 & 1.05 & 35 & 294 & 0.033 & {$[113][114]$} \\
\hline TFC-SR2 & 0.52 & 2.45 & 67 & 361 & 0.027 & {$[115][116]$} \\
\hline
\end{tabular}

${ }^{a}$ determined as average of TFC-S and TFC-SR2 membrane thicknesses due to absence of literature data

${ }^{\mathrm{a}}[58],{ }^{\mathrm{b}}[34],{ }^{\mathrm{c}}[183],{ }^{\mathrm{d}}[184],{ }^{\mathrm{e}}[113],{ }^{\mathrm{f}}[78],{ }^{\mathrm{g}}[185],{ }^{\mathrm{h}}[186],{ }^{\mathrm{i}}[41],{ }^{\mathrm{j}}[95],{ }^{\mathrm{k}}[59],{ }^{1}[187],{ }^{\mathrm{m}}[188],{ }^{\mathrm{n}}[189],{ }^{\mathrm{o}}$ [190], [52], ${ }^{\mathrm{q}}[191], \mathrm{r}[169],{ }^{\mathrm{s}}[192]$ 
Schäfer, A.I. ; Semião, A. ; Akanyeti, I. (2011)

Micropollutant sorption to membrane polymers, Advances in Colloid and Interface Science, 'Membrane Separation and Colloid Science' invited special issue paper (accepted 09/2010).

doi:10.1016/j.cis.2010.09.006

Table 3 Polymer type, supplier, and selected characteristics for polymer powders used in adsorption studies

\begin{tabular}{|c|c|c|c|c|c|c|}
\hline Polymer Name & Supplier & Structure & $\begin{array}{l}\text { Monomer } \\
\text { Molecular } \\
\text { Weight } \\
\text { (g/mol) }\end{array}$ & $\begin{array}{l}\text { Density a } \\
\left(\mathrm{g} / \mathrm{cm}^{3}\right)\end{array}$ & $\begin{array}{c}\text { Refractive } \\
\text { Index } \\
(-)\end{array}$ & $\begin{array}{c}\text { Contact } \\
\text { Angle } \\
\left(0^{\circ}\right)\end{array}$ \\
\hline $\begin{array}{l}\text { Polysulphone } \\
\text { (PSu), (PSu } \\
\text { UDEL) }\end{array}$ & $\begin{array}{l}\text { Goodfellow } \\
\text { \& Solvay }\end{array}$ & & 442 & 1.24 & $1.63^{m}$ & $77^{\circ}$ \\
\hline $\begin{array}{l}\text { Polyester; } \\
\text { Polyethylene } \\
\text { Teraphthalate } \\
\text { (PET) }\end{array}$ & Goodfellow & & 192 & 1.35 & $1.58-1.64^{b}$ & $\begin{array}{l}79.09^{d}, \\
81 e, 70^{f}\end{array}$ \\
\hline $\begin{array}{c}\text { Polyester; } \\
\text { Polyethylene } \\
\text { Naphtalate } \\
\text { (PEN) }\end{array}$ & Goodfellow & & 242 & 1.36 & $1.65-1.90$ & $80^{\circ}$ \\
\hline $\begin{array}{c}\text { Polyamide } \\
\text { Nylon, } 6 \text { (PA) }\end{array}$ & Goodfellow & & 113 & 1.14 & $1.53^{b}$ & $70^{\circ}$ \\
\hline $\begin{array}{l}\text { Polyethersulpho } \\
\text { ne (PES) }\end{array}$ & Goodfellow & & 232 & 1.37 & $1.65^{\circ}$ & $569,72^{f}$ \\
\hline $\begin{array}{l}\text { Polyethersulpho } \\
\text { ne (PES Radel } \\
\text { A) }\end{array}$ & Solvay & & 324 & 1.37 & $1.65^{b}$ & $127^{\mathrm{h}}$ \\
\hline $\begin{array}{l}\text { Polyvinylidene } \\
\text { fluoride (PVDF) }\end{array}$ & Solvay & & 64 & 1.78 & $1.42^{\mathrm{m}}$ & $71^{i}$ \\
\hline $\begin{array}{l}\text { Polystyrene } \\
\text { (PS) }\end{array}$ & Goodfellow & & 104 & 1.05 & $1.59-1.60^{\circ}$ & $911^{\mathrm{e}}$ \\
\hline $\begin{array}{l}\text { Polypropylene } \\
\text { (PP) }\end{array}$ & Goodfellow & & 42 & 0.9 & $1.49^{b}$ & $95^{f}$ \\
\hline $\begin{array}{l}\text { Polyethylene } \\
\text { (HDPE) }\end{array}$ & Goodfellow & & 28 & 0.95 & $1.54^{\mathrm{b}}$ & $93-94 i$ \\
\hline $\begin{array}{c}\text { Poly(2,6 } \\
\text { dimethyl 1,4- } \\
\text { phenylene } \\
\text { oxide) (PPO) }\end{array}$ & Sigma & & 120 & 1.06 & $1.57 \mathrm{~m}$ & $88 j$ \\
\hline
\end{tabular}

\begin{tabular}{|ccccccc|}
\hline $\begin{array}{c}\text { Polyacrylate; } \\
\text { Poly(methyl } \\
\text { methacrylate) } \\
\text { (PMMA) }\end{array}$ \\
Cellulose Sigma
\end{tabular}
a Materials Safety Data Sheet, ${ }^{\mathrm{b}}[193],{ }^{\mathrm{c}}[194],{ }^{\mathrm{d}}[195],{ }^{\mathrm{e}}$ [196], ${ }^{\mathrm{f}}$ [197], ${ }^{\mathrm{g}}$ [198], ${ }^{\mathrm{h}}[199],{ }^{\mathrm{i}}[200],{ }^{\mathrm{i}}$ [201], ${ }^{\mathrm{k}}$ [202],
'[203], ${ }^{\mathrm{m}}[204]$ 


\section{List of Figures}

Figure 1 Steroid retention by different $\mathrm{NF}$ and RO membranes. The hormones represented are: estradiol E2 (272.4 g/mol), estrone E1 (270.4 g/mol), estriol E3 (288 g/mol), ethinylestradiol EE2 (296 g/mol), progesterone P (314.5 g/mol), testosterone T (MW=288.4 g/mol), mestranol ME2 $(\mathrm{MW}=310 \mathrm{~g} / \mathrm{mol}$ ) and diethylstilbestrol DES (MW=268.4 g/mol). The MWCO of the membranes varied between 100 and 560, data adapted from [34, 50, 52, 57, 63, 78, 94, 109, 110, 169, 176].

Figure 2 Micropollutant retention mechanisms in polymeric membranes A: Size Exclusion, B: Charge Repulsion, C: Adsorption, D: Sorption Diffusion, E: Solute-Solute Interactions, and F: Fouling Layer Interactions.

Figure 3 Estradiol filtration by NF270 membrane in MilliQ water at pH 7 and 11. A: Feed and permeate normalized concentration, B: Retention (\%), C: Mass adsorbed $\left(\mathrm{ng} / \mathrm{cm}^{2}\right)$ and D: Estradiol mass flux. The cross-flow conditions were 11 bar, Re $740, \mathrm{~T} 24^{\circ} \mathrm{C}$, feed estradiol concentration 100 $\mathrm{ng} / \mathrm{L}$.

Figure 4 Estrone and Estradiol sorption and retention for several NF membranes as a function of $\mathrm{pH}$. Membranes were not saturated prior to experiments (data adapted from [25, 63, 109, 110]).

Figure 5 Retention and mass adsorbed of estradiol per active (total) surface area and per membrane surface area $\left(100 \mathrm{ng} / \mathrm{L}\right.$ estradiol, $25^{\circ} \mathrm{C}, 11$ bar and Re2800) of several polyamide on polysulphone membranes of increasing pore radius (BW30, NF90, TFC-SR3, NF270 and TFC-SR2, respectively).

Figure 6 Estradiol (E2), estrone (E1), progesterone (P) and testesterone (T) adsorbed on Electrodialysis; Anion Exchange (AEM) (Neosepta ${ }^{\circledR}$ AMX-SB) and Cation Exchange Membrane (CEM) (Neosepta ${ }^{\circledR}$ CMX-SB) (polymer material: Polystyrene Divinylbenzene, supplied by Eurodia, Germany; manufactured by ASTOM Corporation, Japan). Initial hormone concentration was $100 \mathrm{ng} / \mathrm{L}$ in $1 \mathrm{mMNaHCO}_{3}, 85.5 \mathrm{mM} \mathrm{NaCl}$, pH 7 [122].

Figure 7 Mass estrone (E1) adsorbed by polystyrene nanoparticles with different particle size (46, 81, 465 and $3000 \mathrm{~nm}$ ) for different MWCO UF membranes (regenerated cellulose active layer, polypropylene support layer). $1 \mathrm{mM} \mathrm{NaHCO} 3$ buffer and $20 \mathrm{mM} \mathrm{NaCl}$ electrolyte, $\mathrm{pH} 7$, and 5 bar for 1, 3, $5 \mathrm{kDa}$. The mass of polystyrene used was $15.7 \mathrm{mg} / \mathrm{L}$. Filtration process took about $4.5,3.5$ and $2.4 \mathrm{~h}$ for 1,3 and $5 \mathrm{kDa}$ membranes, respectively. (Note that sorption is time dependent due to kinetics).
Figure 8 Total surface area of a hypothetical membrane as a function of thickness for several pore radius assuming cylindrical pores A) with 0.03 porosity, B) 0.1 porosity, C) 0.25 porosity. D) represents the surface area as a function of thickness of a membrane made of a cubic close packing formation of spheres with several sphere radius. The membrane surface area is $100 \mathrm{~cm}^{2}$. The pore radius and thickness cover NF, UF and ED typical pore radius and thicknesses.

Figure 9 Electron-micrographs of the clean NF membranes A TFC-SR, B TFC-S, and C TFC-ULP illustrating enhanced polymer surface area due to surface roughness.

Figure 10 Estradiol adsorption to different pure and membrane polymer powders. A and B: Estradiol mass adsorbed/mass polymer, C and D: Estradiol mass adsorbed/polymer surface estimated from particle size measurements. $60 \mathrm{~mL}$ of $100 \mathrm{ng} / \mathrm{L}$ estradiol solution with $2.5 \mathrm{~g}$ of Polymer, 6 ng initial estradiol mass, no background electrolyte. Filter was not saturated prior to the experiment and minimal losses were observed.

Figure 11 Estrogen adsorption as a function of polymer contact angle. Vertical line is the boundary between low wetting affinity (contact angle $<90^{\circ}$ ) and high wetting affinity $\left(>90^{\circ}\right)$, as described by Mulder [162].

Figure 12 Adsorption of Estrone (E1), Estradiol (E2), Progesterone (P) and Testosterone (T) onto a Polyacrylate fibre and a NF270 membrane in filtration mode as a function of hormone log Kow (data adapted from $[54,205])$.

Figure 13 Selected possible polymer micropollutant interaction mechanisms. A Hydrophobic interaction between the membrane surface and estrone, B Hydrogen bonding between polyamide and estrone, $\mathrm{C} \pi-\pi$ interaction between aromatic rings of polystyrene and estrone, D Cation- $\pi$ interation between the aromatic rings of estrone and functional group of polystyrene-divinylbenzene (Anion Exchange Membrane of electrodialysis membrane). Mechanisms adapted from [30].

Figure 14 Possible hydrogen bonding interactions between estradiol and polyamide, polysulphone, polystyrene and polydimethylphenyleneoxide (ppo). Bold arrows represent strong hydrogen interactions while the dotted arrows represent weak interactions. The head of the arrows point to $\mathrm{H}-$ bonding acceptors. 
Schäfer, A.I. ; Semião, A. ; Akanyeti, I. (2011)

Micropollutant sorption to membrane polymers, Advances in Colloid and Interface Science, 'Membrane Separation and Colloid Science' invited special issue paper (accepted 09/2010).

doi:10.1016/j.cis.2010.09.006

Figure 1

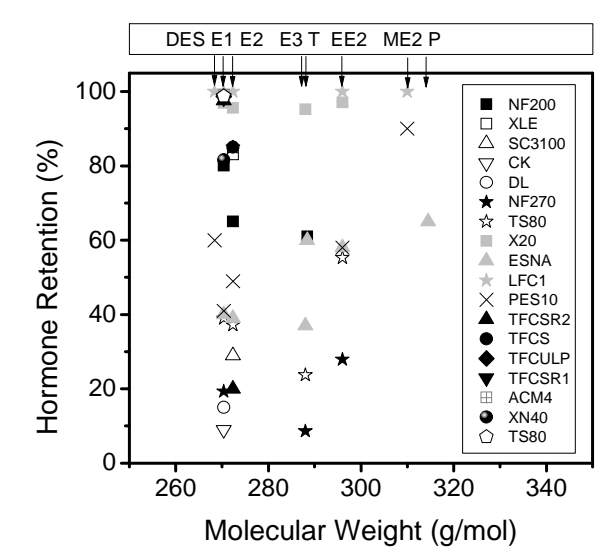

Figure 2

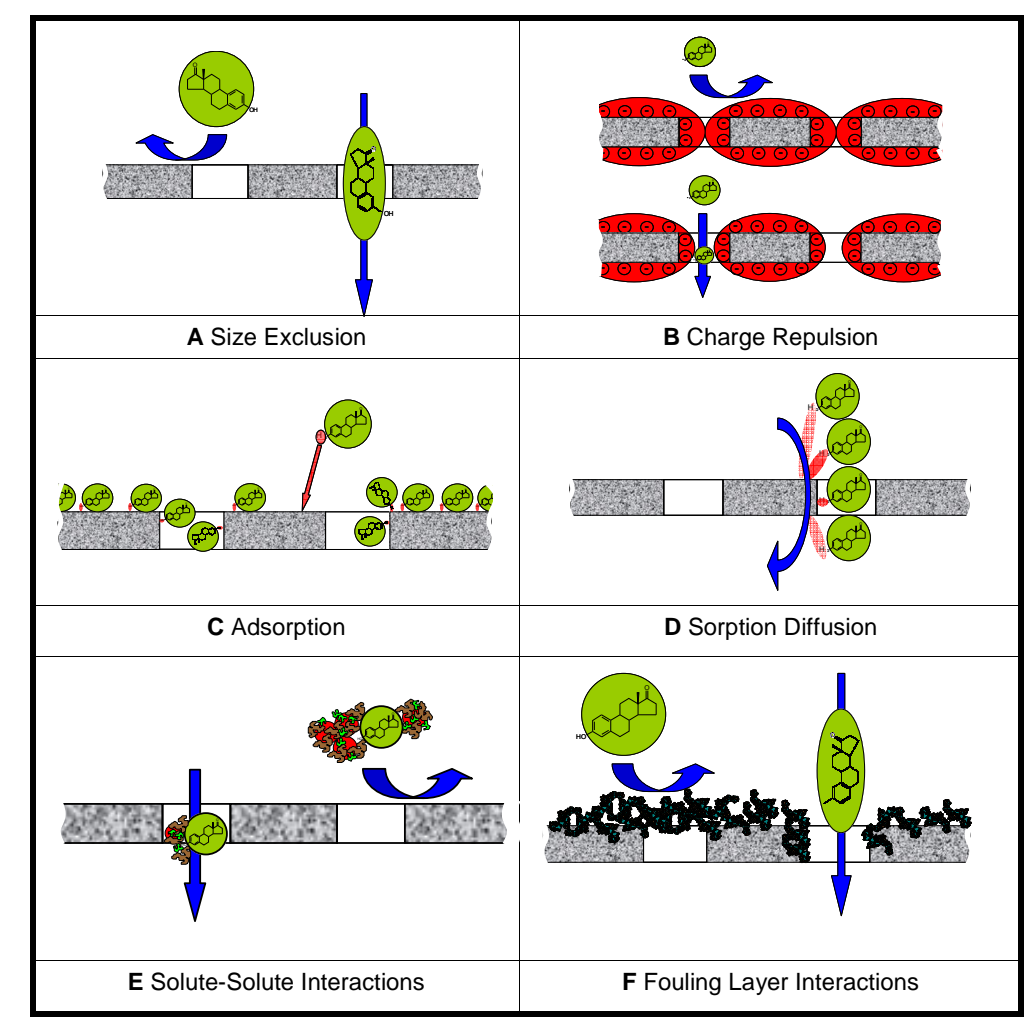


Schäfer, A.I. ; Semião, A. ; Akanyeti, I. (2011)

Micropollutant sorption to membrane polymers, Advances in Colloid and Interface Science, 'Membrane Separation and Colloid Science' invited special issue paper (accepted 09/2010). doi:10.1016/j.cis.2010.09.006

\section{Figure 3}

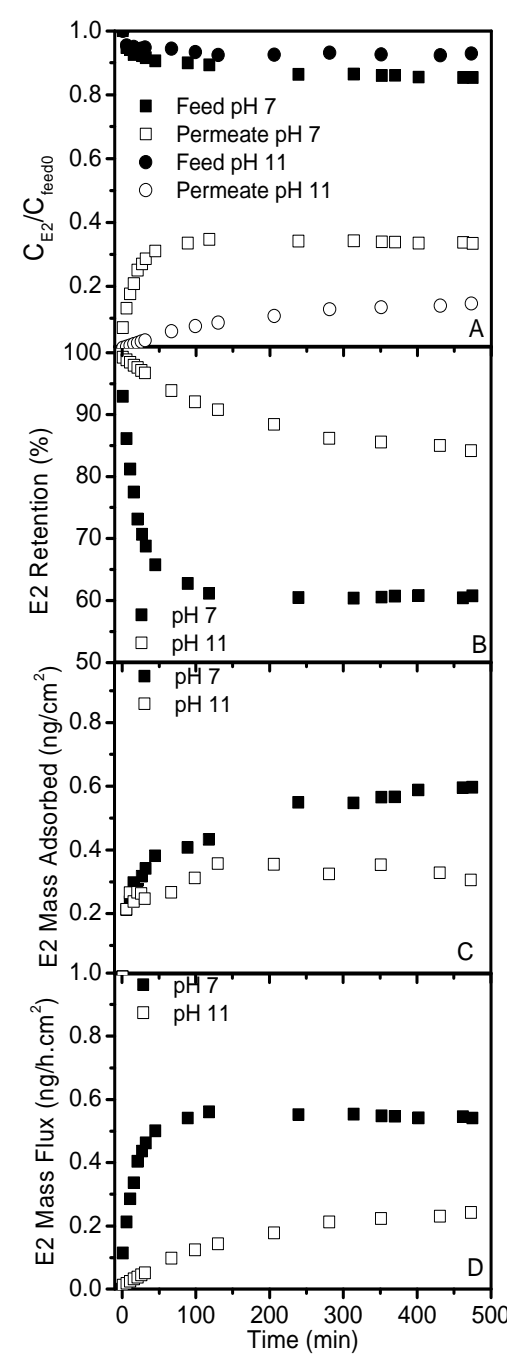

Figure 4

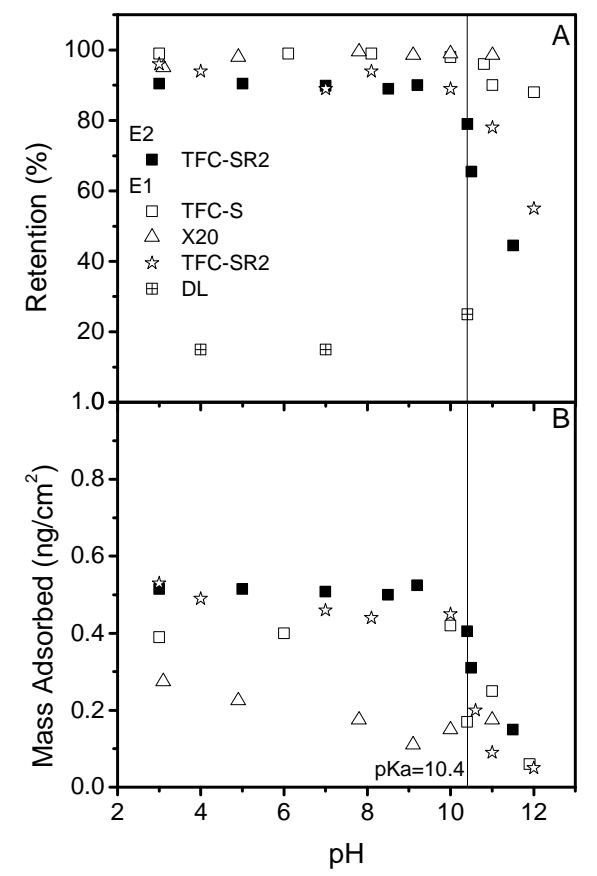


Schäfer, A.I. ; Semião, A. ; Akanyeti, I. (2011)

Micropollutant sorption to membrane polymers, Advances in Colloid and Interface Science, 'Membrane Separation and Colloid Science' invited special issue paper (accepted 09/2010). doi:10.1016/j.cis.2010.09.006

Figure 5

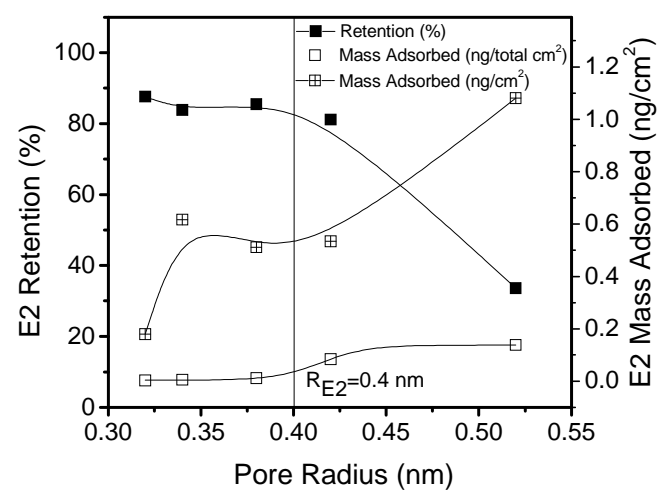

Figure 6

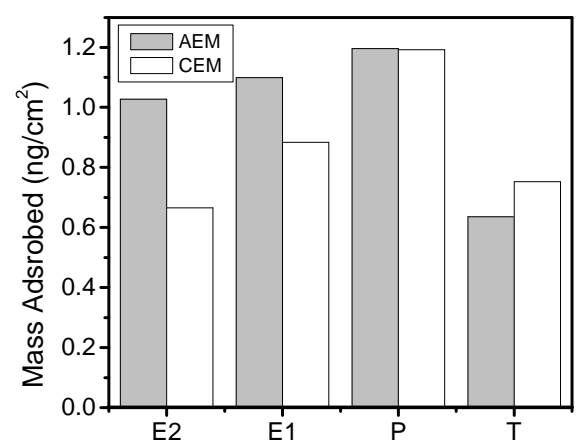


Schäfer, A.I. ; Semião, A. ; Akanyeti, I. (2011)

Micropollutant sorption to membrane polymers, Advances in Colloid and Interface Science, 'Membrane Separation and Colloid Science' invited special issue paper (accepted 09/2010). doi:10.1016/j.cis.2010.09.006

Figure 7

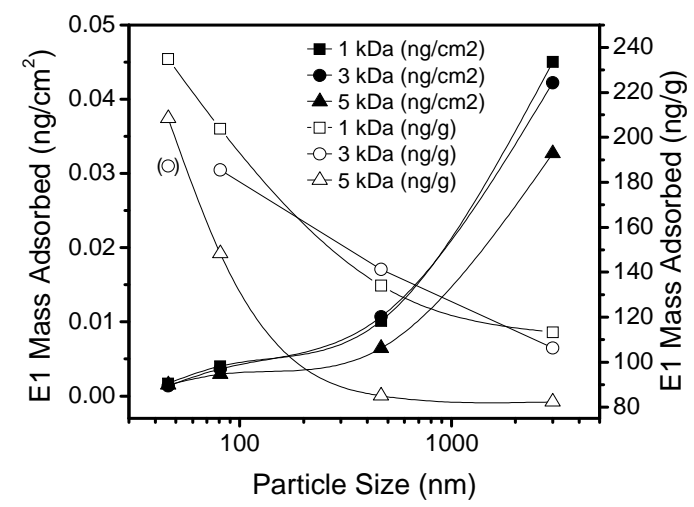

Figure 8

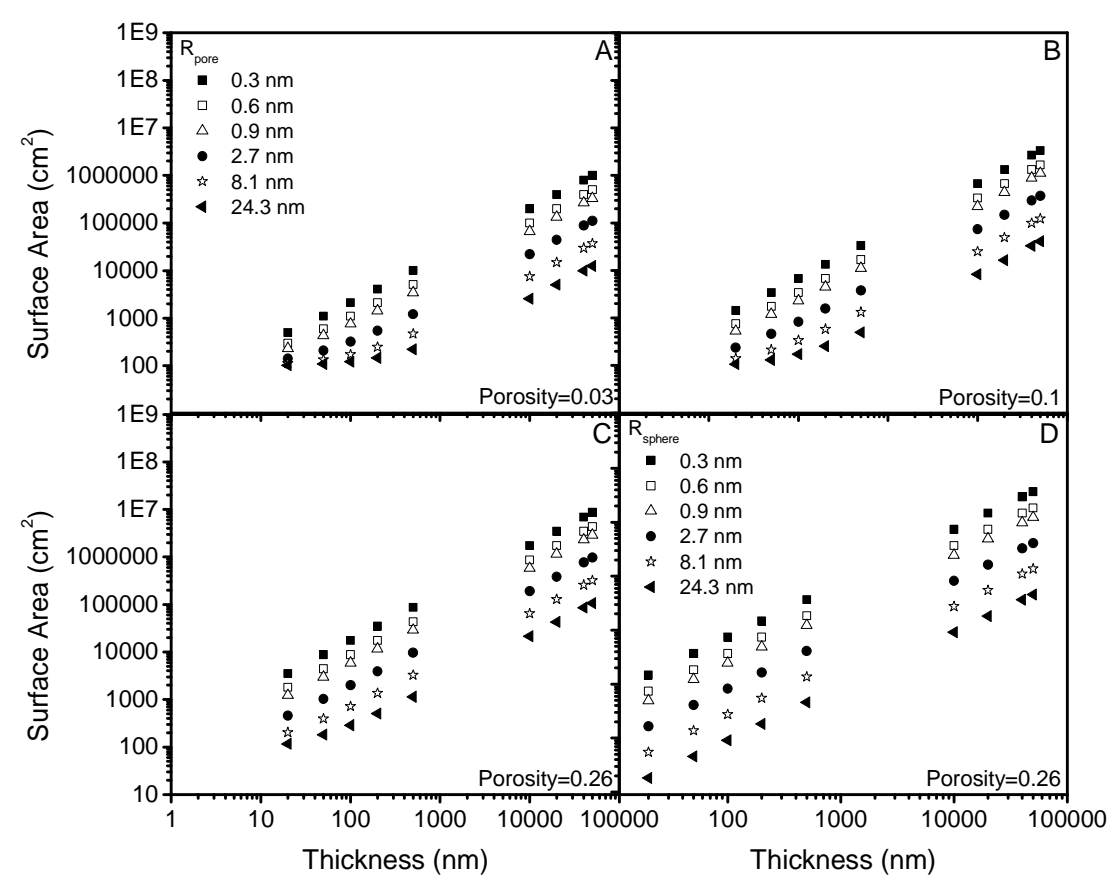


Schäfer, A.I. ; Semião, A. ; Akanyeti, I. (2011)

Micropollutant sorption to membrane polymers, Advances in Colloid and Interface Science, 'Membrane Separation and Colloid Science' invited special issue paper (accepted 09/2010). doi:10.1016/j.cis.2010.09.006

\section{Figure 9}

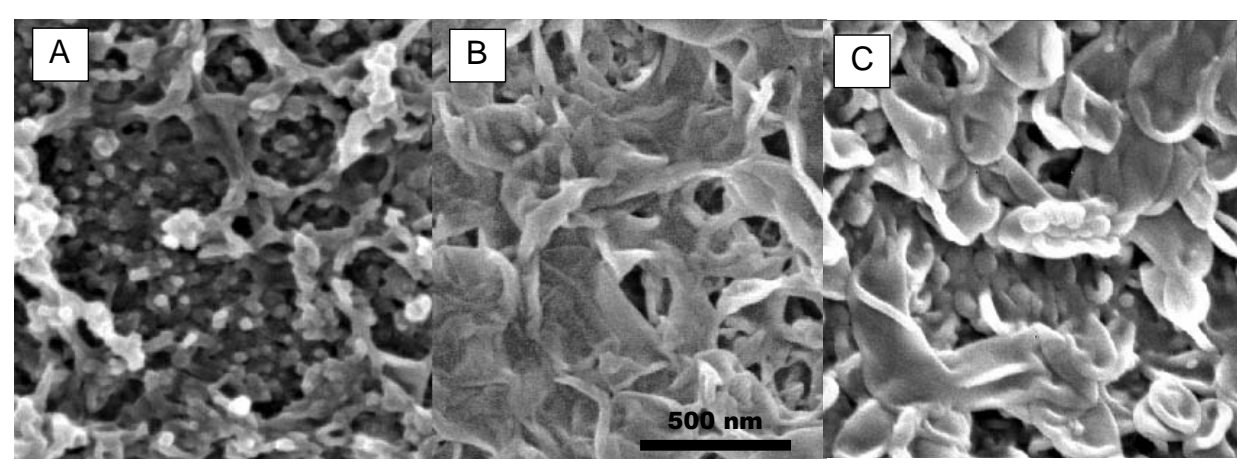

Figure 10

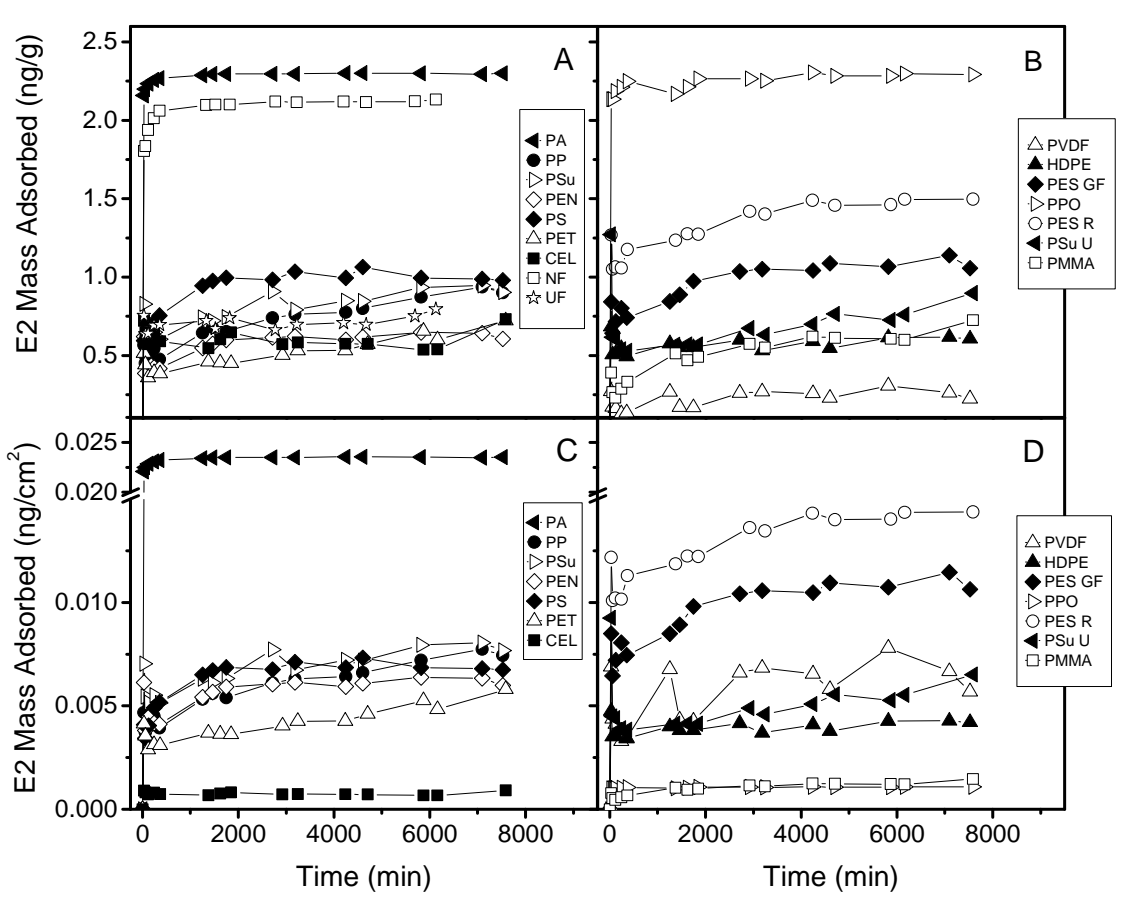


Schäfer, A.I. ; Semião, A. ; Akanyeti, I. (2011)

Micropollutant sorption to membrane polymers, Advances in Colloid and Interface Science, 'Membrane Separation and Colloid Science' invited special issue paper (accepted 09/2010). doi:10.1016/j.cis.2010.09.006

Figure 11

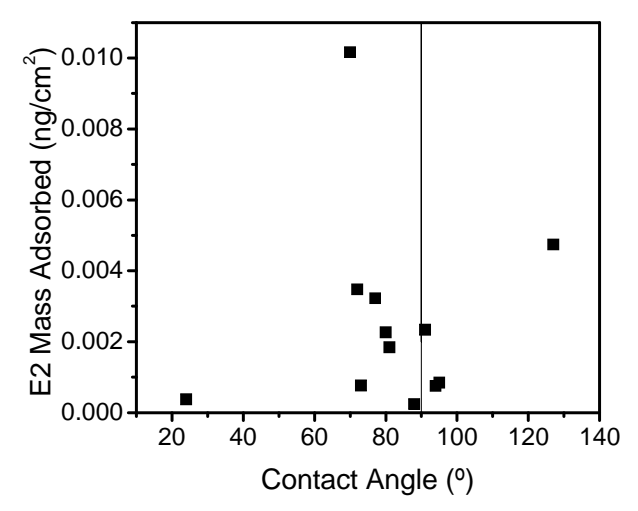

Figure 12

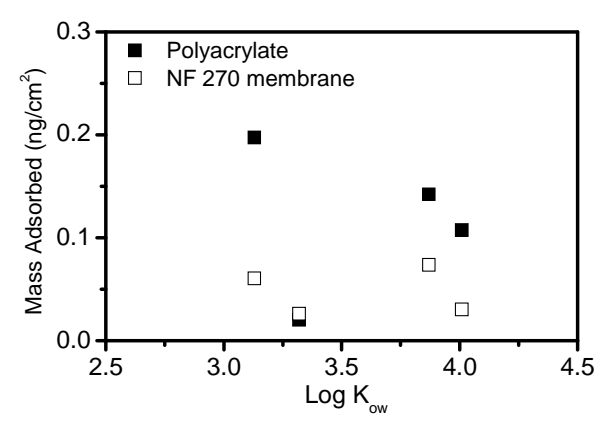


Schäfer, A.I. ; Semião, A. ; Akanyeti, I. (2011)

Micropollutant sorption to membrane polymers, Advances in Colloid and Interface Science, 'Membrane Separation and Colloid Science' invited special issue paper (accepted 09/2010). doi:10.1016/j.cis.2010.09.006

\section{Figure 13}

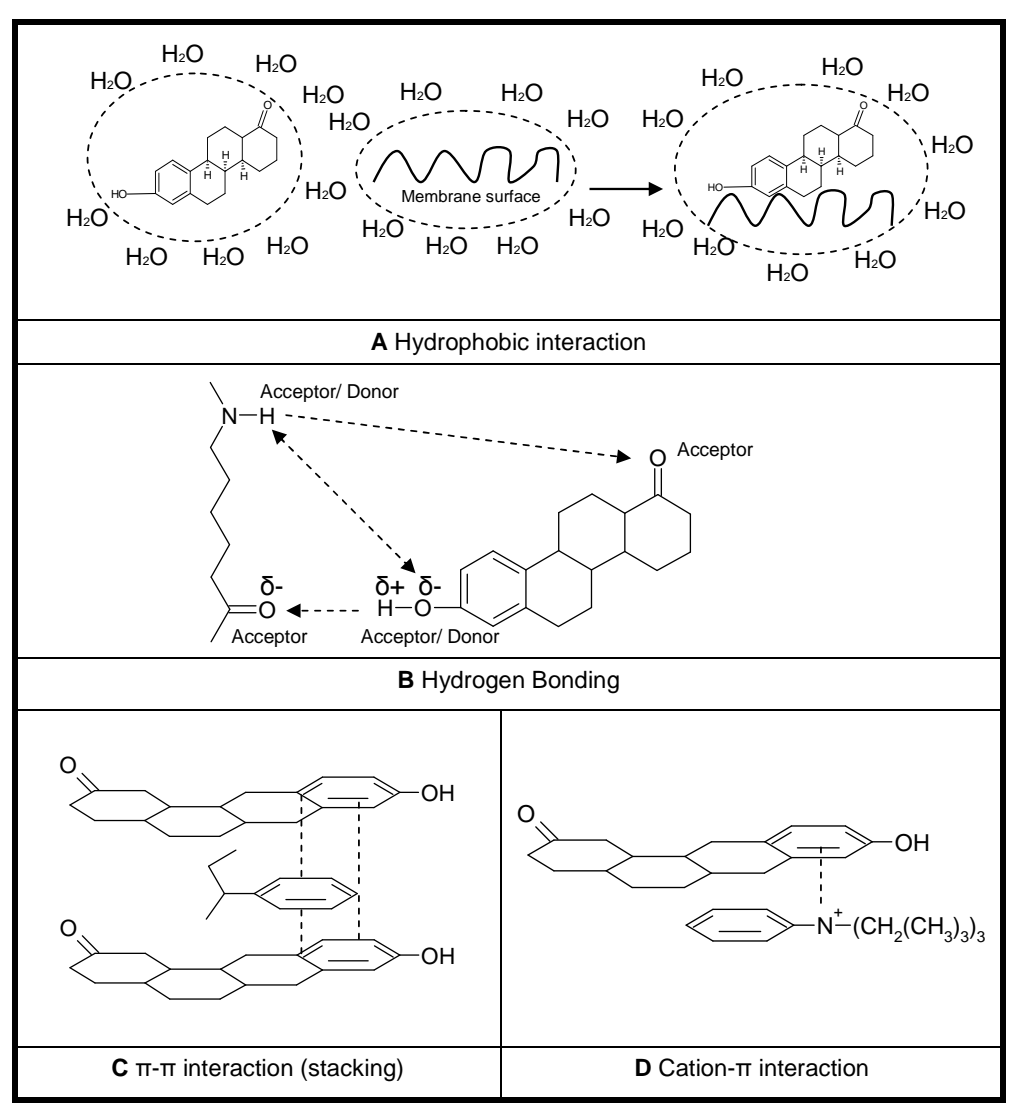

Figure 14

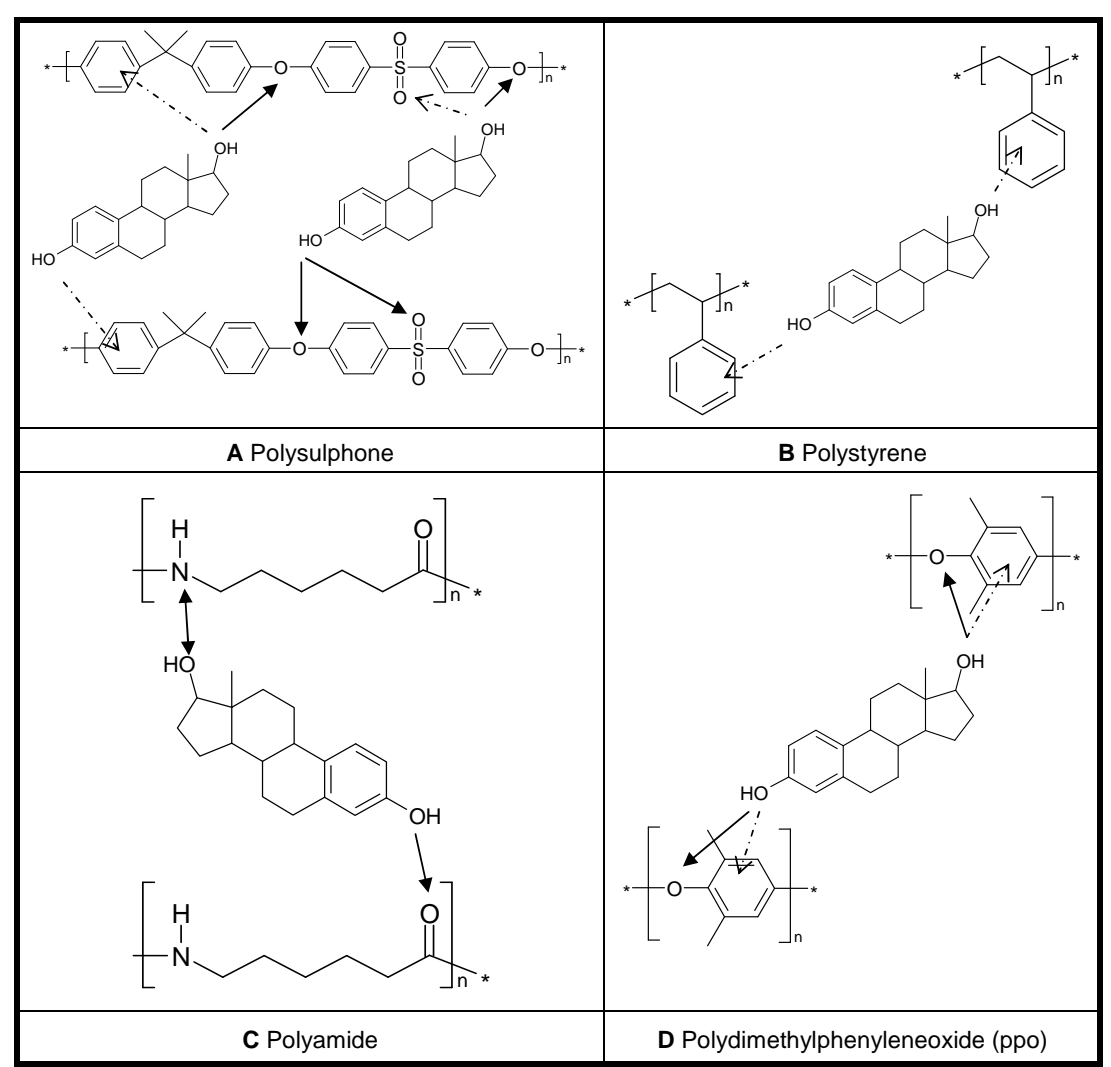

